Article

\title{
Trichoderma hamatum Strain Th23 Promotes Tomato Growth and Induces Systemic Resistance against Tobacco Mosaic Virus
}

\author{
Ahmed Abdelkhalek ${ }^{1, *} \mathbb{0}$, Abdulaziz A. Al-Askar ${ }^{2, *}$, Amr A. Arishi ${ }^{3}$ and Said I. Behiry ${ }^{4}$ (i) \\ 1 Plant Protection and Biomolecular Diagnosis Department, ALCRI, City of Scientific Research and \\ Technological Applications, New Borg El Arab City 21934, Egypt \\ 2 Department of Botany and Microbiology, College of Science, King Saud University, P.O. Box 2455, \\ Riyadh 11451, Saudi Arabia \\ 3 School of Molecular Sciences, The University of Western Australia, Perth, WA 6009, Australia; \\ 22650755@student.uwa.edu.au \\ 4 Agricultural Botany Department, Faculty of Agriculture (Saba Basha), Alexandria University, \\ Alexandria 21531, Egypt; said.behiry@alexu.edu.eg \\ * Correspondence: aabdelkhalek@srtacity.sci.eg (A.A.); aalaskara@ksu.edu.sa (A.A.A.-A.)
}

Citation: Abdelkhalek, A.; Al-Askar, A.A.; Arishi, A.A.; Behiry, S.I. Trichoderma hamatum Strain Th23 Promotes Tomato Growth and Induces Systemic Resistance against Tobacco Mosaic Virus. J. Fungi 2022, 8, 228. https:/ / doi.org/10.3390/jof8030228

Academic Editor: Kuang R. Chung

Received: 23 January 2022

Accepted: 24 February 2022

Published: 25 February 2022

Publisher's Note: MDPI stays neutral with regard to jurisdictional claims in published maps and institutional affiliations.

Copyright: (C) 2022 by the authors. Licensee MDPI, Basel, Switzerland. This article is an open access article distributed under the terms and conditions of the Creative Commons Attribution (CC BY) license (https:// creativecommons.org/licenses/by/ $4.0 /)$

\begin{abstract}
Trichoderma hamatum strain Th23, isolated from tomato roots, was molecularly identified using phylogenetic analysis based on ITS, tef1, and rpb2 gene sequences and evaluated for its efficiency in suppressing tobacco mosaic virus (TMV) infection for the first time. Under greenhouse conditions, the application of Th23 promoted tomato growth with significant increases in shoot and root parameters as well as improved total chlorophyll content. Compared to the nontreated tomato plants, the soil pretreatment of tomato plants $48 \mathrm{~h}$ before TMV inoculation produced a significant reduction in the TMV accumulation level by $84.69 \%$ and enhanced different growth parameters. In contrast, TMV had a deleterious impact on fresh and dry matter accumulation and inhibited photosynthetic capacity. Furthermore, the protective activity of Th2 3 was associated with a significant increase in reactive oxygen species scavenging enzymes (PPO, CAT, and SOD) as well as decreased nonenzymatic oxidative stress markers $\left(\mathrm{H}_{2} \mathrm{O}_{2}\right.$ and MDA) compared to the TMV treatment at 15 days post-viral inoculation (dpi). In addition, considerable increases in the transcriptional levels of polyphenolic genes (HQT and CHS) and pathogenesis-related proteins (PR-1 and PR-7) were shown to induce systemic resistance against TMV. Consequently, the ability of T. hamatum strain Th23 to promote plant growth, induce systemic resistance, and boost innate immunity against TMV infestation supported the incorporation of Th23 as a potential biocontrol agent for managing plant viral infections. To the best of our knowledge, this is the first report of the antiviral activity of T. hamatum against plant viral infection.
\end{abstract}

Keywords: Trichoderma; TMV; enzymes; stress markers; pathogenesis-related proteins; molecular mechanism; tomato

\section{Introduction}

Tobacco mosaic virus (TMV) is a single-stranded positive-sense RNA belonging to the Tobamovirus genus that infects many plant species in several families, primarily tobacco and tomato plants as well as most Solanaceae family plants [1,2]. TMV infection results in mosaic signs on the leaves, yellowing plant tissue, and significant economic losses worldwide [3]. Since TMV has an extensive host range, it has a devastating effect on the hosts' yields. New approaches to controlling TMV are required because of the shortage of suitable and effective control [4]. Biological control agents have long been shown to improve plant defense systems and lower disease severity and incidence. Among the biological control agents that have proven to have a reasonable degree of pathogen control, plant growth-promoting fungi (PGPF) are well known for their ability to minimize the disease incidence of many fungal, bacterial, and viral plant pathogens and trigger plant 
defense reactions [5]. The use of beneficial Trichoderma fungi to prevent viral plant diseases has attracted interest because it is a safe and environmentally friendly method of controlling pathogens [6].

Trichoderma spp. are free-living parasitized fungi known as bioagents because of their competency to suppress or even kill phytopathogens $[7,8]$. They can also elicit a host immune response against pathogenic microbes with potential benefits for vegetative growth [9] and enhance photosynthetic rates and respiration reactions by reconfiguring plant gene transcription [10]. In tomatoes, Trichoderma hamatum successfully induced resistance to Botrytis cinerea and Xanthomonas vesicatoria [11,12]. Mastouri et al. [13] found that treating tomato seeds with $T$. harzianum relieved various biotic and abiotic stressors. Thus, after colonizing roots, Trichoderma species can interact well with plants, and in some cases, chemically operate as endophytic symbiotic organisms. As a result, they can modify the activation of many plant genes and even plant physiology [14]. Through studying several molecular and biochemical components of host-virus interaction and establishing the precise role of ROS, it was reported that T. harzianum had positive effects on the tomato defense system against cucumber mosaic virus (CMV) infection [15].

Plants generally compensate for diseases through a variety of cellular processes including (i) up- or downregulation of certain genes; (ii) changes in the levels of different compounds known to play a role in the host defense pathway including reactive oxygen species (ROS); (iii) increased expression of particular transcriptional regulators, defensive scheme genes, and heat-shock proteins; and (iv) improvement in the mobility of biomolecules, enzymes, and growth factors involved [16,17]. Pathogenesis-related proteins (PRs) are primarily found in the systemic acquired resistance (SAR) pathway and are potent as antipathogenic agents [18]. Furthermore, Singh et al. [19] found that biotic inducers raised the levels of several PRs such as peroxidase and chitinase isozymes. The increase in $P R-1$ as a SA molecular marker gene is closely linked to the activation of salicylic acid (SA) during pathogen infection and a variety of physiological responses in plants in response to biotic stressors [20,21]. Polyphenolic substances are among the secondary metabolites that play a significant role in plant development, growth, and tolerance to biotic and abiotic stresses [22]. The biochemical and molecular research on the host-pathogen-antagonist relationship is critical for understanding the dynamics of infectious diseases. By penetrating the plant epidermal tissues, Trichoderma spp. has the capability to colonize plant roots, which usually results in triggering different metabolic pathways by modifying gene expression $[23,24]$. It has been observed that when a plant comes into contact with a pathogen, a SAR mechanism is triggered, but when it comes into contact with a nonpathogenic organism, an ISR mechanism is activated [25,26]. Many studies have used transcriptional analysis to determine the expression of defense genes and proteins in response to Trichoderma-induced resistance (TIR) against various pathogens, which has established that TIR is preceded by the upregulation of genes encoding vital defense enzymes and PR-proteins $[27,28]$. T. hamatum UoM13 was reported as a mediator of plant systemic immunity by significantly increasing the activity of SA-inducible genes such as glucanase, $P P O, P O X, P A L, P R-1$, and $P R-5$, all of which are considered essential SAR markers [27].

Although there is already evidence that Trichoderma spp. has a role in viral disease resistance in plants, there have been no previous studies exploring alterations in plant physiology and antiviral activities of T. hamatum against plant viral infections. The primary goal of this investigation was to isolate, identify, and evaluate the protective activity of the T. hamatum strain Th23 against TMV infection under controlled greenhouse conditions for the first time. Moreover, the effects of Th23 on the viral symptom appearance, tomato growth parameters, chlorophyll content, and the accumulation level of TMV inside infected tissues were estimated. Furthermore, the transcriptional level changes of two polyphenolic genes, hydroxycinnamoyl Co A quinate hydroxycinnamoyl transferase (HQT) and chalcone synthase (CHS), and three PR proteins ( $P R-1, P R-2$, and $P R-7)$ as well as some defense enzymes including polyphenol oxidase (PPO), catalase (CAT), and superoxide dismutase 
(SOD) were evaluated. The ability to use Th23 against TMV infection could be crucial for developing a thorough understanding of the plant-pathogen-bioagent complex and building effective viral disease control strategies.

\section{Materials and Methods}

\subsection{Collecting, Isolating, and Identifying Samples}

Trichoderma isolate was obtained from soil rhizosphere samples collected from tomatogrowing areas in Egypt's El-Behira governorate. Using the Trichoderma TSM specific media, the antagonistic isolate was isolated using the serial dilution plate method by Elad et al. [29]. The resultant fungal colonies were purified using the hyphal tip separation procedure, and the fungus was kept on potato dextrose agar (PDA) (HiMedia Laboratories Pvt. Limited, Mumbai, India) for further examination. To identify the isolate, the ITS, rpb2, and tef1 genes (Table 1) were used as well as the morphological traits. In PCRs, a $1 \mu \mathrm{L}$ volume of each primer pair (10 pmole), $20 \mu \mathrm{L}$ of $2 x$ MyTaq Red Mix (Bioline Inc., Ansan, Korea), $2 \mu \mathrm{L}$ of fungus DNA, and $26 \mu \mathrm{L}$ of molecular grade water were used. Cycling was performed as follows in a gradient SureCycler (Agilent Technologies, Santa Clara, CA, USA): an initial step at $94{ }^{\circ} \mathrm{C}$ for $5 \mathrm{~min}$, followed by 40 cycles at $95^{\circ} \mathrm{C}, 55^{\circ} \mathrm{C}$, and $72{ }^{\circ} \mathrm{C}$ each for $1 \mathrm{~min}$, and a final extension step at $72{ }^{\circ} \mathrm{C}$. After sequencing the PCR amplicons, the nucleotide sequences were aligned using MEGA $X$ software. The resulting sequences were compared to those in the GenBank database using the NCBI-BLAST tool.

Table 1. Sequences of primers used in this study.

\begin{tabular}{|c|c|c|c|c|}
\hline Primer Code & Target Gene & Direction & Nucleotide Sequences $\left(5^{\prime}-3^{\prime}\right)$ & References \\
\hline ITS & Internal Transcribed Spacer & $\begin{array}{l}\text { Forward } \\
\text { Reverse }\end{array}$ & $\begin{array}{l}\text { TCCGTAGGTGAACCTGCGG } \\
\text { TCCTCCGCTTATTGATATGC }\end{array}$ & {$[30]$} \\
\hline$r p b 2$ & RNA polymerase II subunit 2 & $\begin{array}{l}\text { Forward } \\
\text { Reverse }\end{array}$ & $\begin{array}{l}\text { GAYGAYMGWGATCAYTTYGG } \\
\text { CCCATRGCTTGYTTRCCCAT }\end{array}$ & {$[31]$} \\
\hline tef1 & Translation elongation factor 1 alpha & $\begin{array}{l}\text { Forward } \\
\text { Reverse }\end{array}$ & $\begin{array}{c}\text { CATCGAGAAGTTCGAGAAGG } \\
\text { AACTTGCAGGCAATGTGG }\end{array}$ & [32] \\
\hline$T M V-C P$ & Tobacco mosaic virus-coat protein & $\begin{array}{l}\text { Forward } \\
\text { Reverse }\end{array}$ & $\begin{array}{l}\text { ACGACTGCCGAAACGTTAGA } \\
\text { CAAGTTGCAGGACCAGAGGT }\end{array}$ & [33] \\
\hline$P R-1$ & Pathogenesis related protein-1 & $\begin{array}{l}\text { Forward } \\
\text { Reverse }\end{array}$ & $\begin{array}{l}\text { CCAAGACTATCTTGCGGTTC } \\
\text { GAACCTAAGCCACGATACCA }\end{array}$ & [34] \\
\hline$P R-2$ & $\beta$-1,3-glucanases & $\begin{array}{l}\text { Forward } \\
\text { Reverse }\end{array}$ & $\begin{array}{l}\text { TATAGCCGTTGGAAACGAAG } \\
\text { CAACTTGCCATCACATTCTG }\end{array}$ & [34] \\
\hline$P R-7$ & Proteinase & $\begin{array}{l}\text { Forward } \\
\text { Reverse }\end{array}$ & $\begin{array}{l}\text { AACTGCAGAACAAGTGAAGG } \\
\text { AACGTGATTGTAGCAACAGG }\end{array}$ & [34] \\
\hline CHS & Chalcone synthase & $\begin{array}{l}\text { Forward } \\
\text { Reverse }\end{array}$ & $\begin{array}{l}\text { CACCGTGGAGGAGTATCGTAAGGC } \\
\text { TGATCAACACAGTTGGAAGGCG }\end{array}$ & [35] \\
\hline$H Q T$ & $\begin{array}{l}\text { Hydroxycinnamoyl Co A: quinate } \\
\text { hydroxycinnamoyl transferase }\end{array}$ & $\begin{array}{l}\text { Forward } \\
\text { Reverse }\end{array}$ & $\begin{array}{l}\text { CCCAATGGCTGGAAGATTAGCTA } \\
\text { CATGAATCACTTTCAGCCTCAACAA }\end{array}$ & {$[35]$} \\
\hline$\beta$-actin & Beta-actin & $\begin{array}{l}\text { Forward } \\
\text { Reverse }\end{array}$ & $\begin{array}{l}\text { ATGCCATTCTCCGTCTTGACTTG } \\
\text { GAGTTGTATGTAGTCTCGTGGATT }\end{array}$ & [36] \\
\hline
\end{tabular}

\subsection{TMV Isolate, Inoculum Preparation, and Greenhouse Investigation}

The tobacco mosaic virus (TMV) strain KH1 (MG264131) used in this study has been previously characterized [37]. To prepare $20 \mu \mathrm{g} / \mathrm{mL}$ of TMV inoculum, the concentration was adjusted with $100 \mathrm{mM}$ phosphate buffer, $\mathrm{pH}$ 7. The tomato virus-free Carmen F1 seeds (Nongwoo Bio, Co. Ltd., Gyunggi-do, Suwon, Korea) were sown in a controlled greenhouse in trays prefilled with peat moss mixture. After three weeks, the seedlings were transported into $25 \mathrm{~cm}$ pots, and each pot was filled with five kilograms $(\mathrm{kg})$ of sand and clay (1:1). Trichoderma inoculum was prepared by serial dilution and used as $5 \mathrm{~mL} / \mathrm{kg}$ 
at a $1 \times 10^{8}$ spores $/ \mathrm{mL}$ concentration. A week later, the two upper leaves of each tomato seedling were dusted with carborundum and gently mechanically inoculated with $1 \mathrm{~mL}$ of semi-purified TMV [38].

There were four treatments in the trial; each treatment consisted of three replicates, and every replicate had a three-pot. The tomato plants treated with TMV-free inoculum buffer and foliar sprayed with sterile water served as the control (mock treatment). Plants mechanically inoculated with TMV only were used as the TMV treatment. Plants inoculated with Trichoderma hamatum only were identified as the Th23 treatment. Plants were inoculated with T. hamatum $48 \mathrm{~h}$ before being mechanically inoculated with TMV (Th23 + TMV treatment). All of the plants were kept in the greenhouse at a temperature of $28 \pm 2{ }^{\circ} \mathrm{C} /$ $18 \pm 2{ }^{\circ} \mathrm{C}$ at day/night and 75\% relative humidity. The TMV symptoms were observed, day after day. At 15 days post-viral inoculation (dpi), nine leaves collected from three plants per pot were combined and ground for total chlorophyll content quantification by a SPAD-502Plus meter (Konica Minolta, Inc., Tokyo, Japan) as well as the enzyme activity estimations and RNA extraction. The plant's length and fresh and dried weights of each treatment's shoot and root systems $(\mathrm{g})$ were assessed.

\subsection{Determination of Enzyme Activity}

All of the fine chemicals used in this section were purchased from Sigma-Aldrich (St. Louis, MO, USA) and all measurements were performed by a UV-Vis spectrophotometer (EMCLAB Instruments GmbH, Duisburg, Germany).

\subsubsection{Oxidative Stress Markers \\ Malondialdehyde}

The thiobarbituric acid (TBA) method [39] was used to determine the malondialdehyde (MDA) content in plant leaves. The leaves were pulverized with $0.1 \%$ trichloroacetic acid (TCA) and centrifuged at $12,000 \times g$ for $30 \mathrm{~min}$. After that, the supernatants were incubated with a mixture of TCA and TBA $(4: 1 \mathrm{v} / \mathrm{v})$ for $30 \mathrm{~min}$. Then, all the mixes were quickly chilled. The MDA content was measured at $600 \mathrm{~nm}$ and expressed as $\mu \mathrm{M} / \mathrm{g}$ fresh weight (FW).

\section{Hydrogen Peroxide}

To determine the amount of hydrogen peroxide $\left(\mathrm{H}_{2} \mathrm{O}_{2}\right)$ in tomato leaves, the samples were homogenized with $0.1 \%$ TCA [40]. Equal amounts of the supernatant, $10 \mathrm{mM}$ of potassium dihydrogen phosphate $(\mathrm{pH} 7)$, and potassium iodide $(1 \mathrm{M})$ were mixed and left at $25{ }^{\circ} \mathrm{C}$ for $15 \mathrm{~min}$., then centrifuged at $12,000 \times \mathrm{g}$ for $10 \mathrm{~min}$. The resultant supernatant absorbance was measured at $390 \mathrm{~nm}$. The quantity of $\mathrm{H}_{2} \mathrm{O}_{2}$ was expressed as $\mu \mathrm{M} / \mathrm{g} F W$.

\subsubsection{Antioxidant Enzymes}

The extracts used in this section were obtained by pulverizing tomato leaves in phosphate buffer and spun at $12,000 \times g$ for $30 \mathrm{~min}$. The pellets were discarded, and the extracts were preserved at $-20{ }^{\circ} \mathrm{C}$ until used.

\section{Polyphenol Oxidase}

The polyphenol oxidase (PPO) enzyme was determined using a mixture of enzyme extract, Tris- $\mathrm{HCl}\left(50 \mathrm{mM}, \mathrm{pH}\right.$ 6), and quinone (1:2:1, v/v/v), then left at $25^{\circ} \mathrm{C}$ for $10 \mathrm{~min}$ [41]. The absorbance was measured at $420 \mathrm{~nm}$ and expressed in $\mu \mathrm{M} / \mathrm{g}$ FW.

\section{Catalase}

The catalase (CAT) activity was conducted by mixing $478.5 \mu \mathrm{L}$ of $25 \mathrm{mM}$ potassium phosphate buffer containing in a final concentration $10 \mathrm{mM} \mathrm{H}_{2} \mathrm{O}_{2}$ and $12.5 \mu \mathrm{L}$ of enzyme extract [42]. The CAT activity was determined by decomposing the $\mathrm{H}_{2} \mathrm{O}_{2}$ in $1 \mathrm{~min}$ at $240 \mathrm{~nm}$ and expressed as $\mu \mathrm{M} / \mathrm{g}$ FW. 
Superoxide Dismutase

The superoxide dismutase (SOD) enzyme determination method was conducted with minor modifications [43]. A mixture of $50 \mathrm{mM}$ potassium dihydrogen phosphate (pH 7.8), $0.1 \mathrm{mM}$ ethylenediaminetetraacetic acid, $75 \mathrm{mM}$ nitro blue tetrazolium, $10 \mathrm{mM}$ L-methionine, and $20 \mathrm{mM}$ riboflavin were left to react with $100 \mu \mathrm{L}$ of enzyme extract at room temperature under fluorescent lamps for $20 \mathrm{~min}$ before being placed in the dark. The activity of SOD was measured at 560 and expressed as mol/g FW.

\subsection{Analysis of Defense-Related Genes}

\subsubsection{Extraction of RNA and cDNA Synthesis}

Three biological duplicates of each treatment's leaves were collected at $15 \mathrm{dpi}$ and stored at $80^{\circ} \mathrm{C}$ until usage. A GeneJET RNA Purification Kit was used to isolate the total RNA (Thermo Fisher Scientific Co., Waltham, MA, USA). Each biological sample was made up of nine distinct samples from nine different plants. The purity of the isolated RNA was measured using UV-Vis spectroscopy (EMCLAB Instruments GmbH, Duisburg, Germany). Each sample was reverse transcribed to cDNA with GoScript ${ }^{\mathrm{TM}}$ Reverse Transcriptase (Promega, WI, USA) using a mix of oligo dT and hexamer random primers. In a gradient SureCycler (Agilent Technologies, Santa Clara, CA, USA), the RT-PCR reaction was carried out at $42{ }^{\circ} \mathrm{C}$ for $1 \mathrm{~h}$ and then deactivated at $80{ }^{\circ} \mathrm{C}$ for $5 \mathrm{~min}$. The cDNA amplicons were stored at $20^{\circ} \mathrm{C}$ until they were used in qRT-PCR.

\subsubsection{Quantitative Real-Time PCR (qRT-PCR) Assays}

The accumulation levels of TMV coat protein gene (TMV-CP) as well as the transcriptional levels of three PR-proteins $(P R-1, P R-2$, and $P R-7)$ and two phenylpropanoid pathway genes (CHS and $H Q T$ ) were investigated. The primer sequences are presented in Table 1. The ratio of the expression of the TMV-CP gene and the housekeeping gene in tomato plants was used to calculate the viral accumulation level. The $\beta$-actin gene was used as a housekeeping gene to standardize the expression levels of all genes $[44,45]$. For the qRT-PCR assay, each biological treatment was carried out in three replicates using the GoTaq ${ }^{\circledR}$ qPCR Master Mix (Promega, Wisconsin, USA) on PikoReal (Real-Time PCR, Thermo Fisher Scientific Co., Waltham, MA, USA) as previously reported [46]. The $2^{-\Delta \Delta C T}$ method [47] was used to precisely quantify and calculate the relative transcriptional level of each tested gene.

\subsection{Statistical Analysis}

All data were statistically evaluated using the least significant difference (LSD) at a 0.05 probability using CoStat software (ANOVA). Gene expression (upregulation) was indicated by relative transcriptional levels greater than 1 , whereas gene expression (downregulation) was indicated by values less than 1 .

\section{Results}

\subsection{Isolation and Identification of Trichoderma Isolate}

The morphological analysis of the isolated Trichoderma isolate from tomato plant roots was compatible with the Trichoderma genus features according to the common taxonomic phenotypical criteria. Its conidia were green in color, single-celled, oval, smooth, or rough. Conidiophores were long, branching, and not whorly, with solo phialides or in-groups arising from tiny terminal bunches at a $90^{\circ}$ angle from the conidiophore. A PCR technique was used to confirm the morphological identification of the Trichoderma isolate by amplifying PCR amplicons of three genes of ITS, rpb2, and tef1 with approximately 600 , 1050, and $500 \mathrm{bp}$, respectively. 
The partial sequences of the three amplified genes ITS, rpb2, and tef1 were obtained, then submitted to NCBI GenBank, and were assigned to Trichoderma hamatum strain Th23 with accession numbers MW797032, OL412667, and OL439486, respectively. A comparison of the generated ITS region nucleotide sequence of the T. hamatum strain Th23 with the GenBank identified isolates demonstrated that the genetic homogeneity closest to $99 \%$ of the ITS sequence was with Trichoderma spp. (MH285237 and MK871313), T. hamatum (MN176381), and T. asperellum (JX173862) (Figure 1A). Comparing the T. hamatum strain Th23 rpb2 nucleotide sequence with those isolates of T. hamatum in the GenBank database clarified that the highest homogeneity was 100\% with T. hamatum (AB853847 and EU883555) (Figure 1B). The maximum nucleotide sequence similarity of the tef1 gene $(100 \%)$ was observed with T. hamatum isolates from different countries (MK800143, KU738444, and AY750893) (Figure 1C).

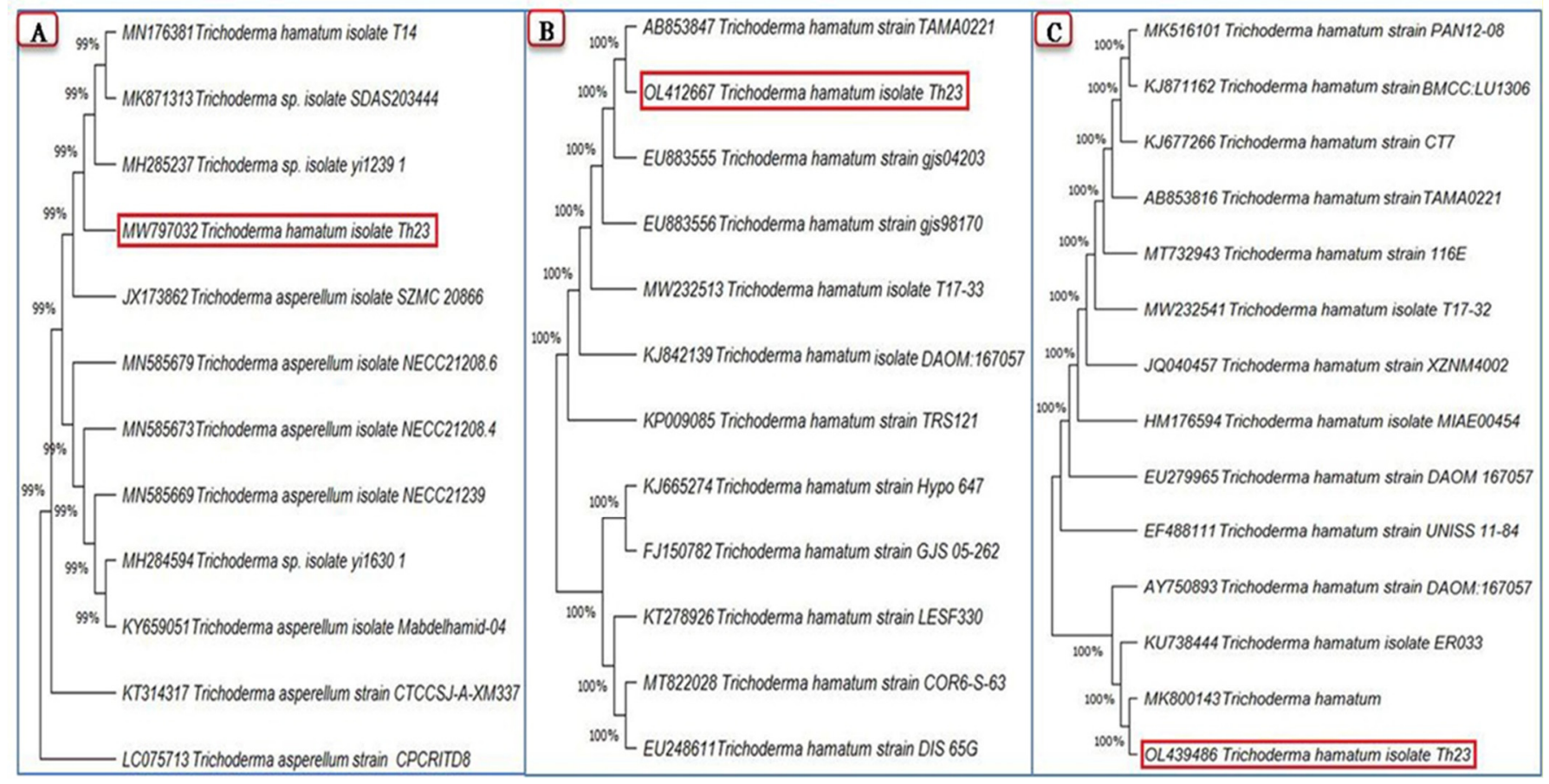

Figure 1. Phylogenetic trees show the relationship of the Trichoderma hamatum strain Th23 (shown in a red rectangle) among closely related Trichoderma isolates from GenBank based on partial sequences of three genes: ITS (A), rpb2 (B), and tef1 (C) generated by MEGA X software.

3.2. Effect of Th23 on Viral Symptoms Development, Tomato Plants Growth Parameters, and Total Chlorophyll Content

Under greenhouse conditions, the protective activity of Trichoderma hamatum strain Th23 (anti-TMV) was evaluated on tomato plants. Compared to nontreated plants, Th23 + TMV treatment considerably reduced the disease symptoms and enhanced plant development. The TMV characteristic symptoms started to appear on tomato leaves of TMV-inoculated plants (TMV treatment) at $12 \mathrm{dpi}$ and ended with a severe mosaic pattern and yellowing symptoms at $15 \mathrm{dpi}$ (Figure 2). On the other hand, a five-day delay with mild mosaic symptom development was observed in the Th23 + TMV treatment tomato plants. No TMV signs were observed on tomato plants treated with Th23 or the mock (control) (Figure 2). 


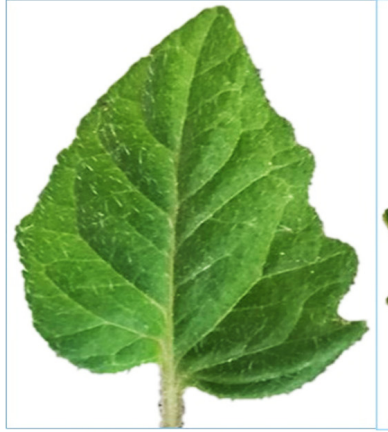

Mock treatment

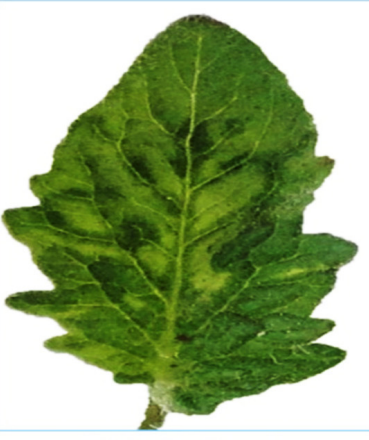

TMV treatment

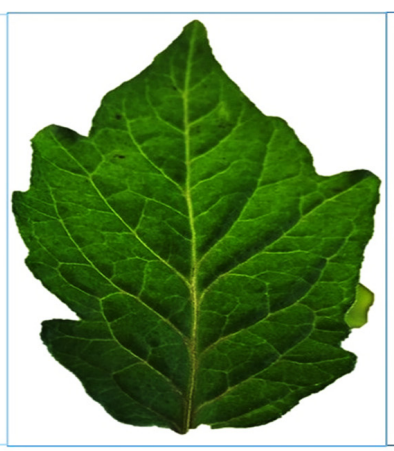

Th23 treatment

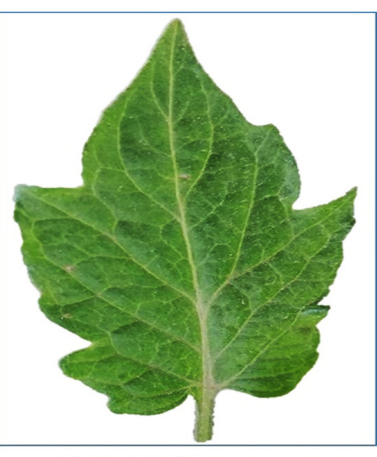

Th23+TMV treatment

Figure 2. The protective activity of Trichoderma hamatum isolate Th23 against TMV on tomato leaves at 15 dpi (Th23 + TMV treatment). TMV treatment showed mild mosaic symptoms compared to Th23 and the mock treatments showed no developed symptoms.

Compared to the mock and TMV treatments, the Th23 and Th23 + TMV treatments had a significant impact $(p \leq 0.05)$ on the shoot and root system characteristics (Table 2). For growth parameters, shoot, and root, the Th23 treatment exhibited the highest values, followed by the Th23 + TMV treatment. The Th23 treatment showed the highest shoot length $(40.31 \mathrm{~cm})$, fresh $(11.33 \mathrm{~g})$, and dry $(4.08 \mathrm{~g})$ weights, which recorded an increase in percentages of $74.35 \%, 91.06 \%$, and $42.16 \%$, respectively (Table 2). On the other hand, Th23 + TMV treatment exhibited significant increases of $50.22 \%, 27.15 \%$, and $11.85 \%$ for shoot length, fresh, and dry weights, respectively (Table 2). Compared to the mock treatment, the tomato plants treated with TMV alone showed a considerable reduction in the shoot system's length, fresh, and dry weights, recorded at $23.12 \mathrm{~cm}, 5.93 \mathrm{~g}$, and $2.87 \mathrm{~g}$, respectively. Similarly, significant $(p \leq 0.05)$ increases in length or fresh and dry weights of the root system by $95.08 \%, 94.75 \%$, and $45.05 \%$ were recorded after treatment of the tomato plant with Th23 (Table 3). Moreover, Th23 + TMV treatment revealed significant increases in the length or fresh and dry weights of the root system of tomato plants, which reached $14.56 \mathrm{~cm}, 4.75 \mathrm{~g}$, and $2.05 \mathrm{~g}$ with an increasing percentage of $49.18 \%, 55.74 \%$, and $12.64 \%$, respectively (Table 3 ). In contrast, significant reductions in the root system parameters were detected after infection with TMV in nontreated tomato plants (Table 3).

Table 2. The effect of different treatments of Th23 and TMV inoculation on the length, fresh, and dry weights of the shoot system in tomato plants.

\begin{tabular}{|c|c|c|c|c|c|c|}
\hline \multirow{2}{*}{ Treatment } & \multicolumn{6}{|c|}{ Shoot \pm SD * } \\
\hline & Length (cm) & Increase $(\%)$ & Fresh Weight (g) & Increase (\%) & Dry Weight (g) & Increase $(\%)$ \\
\hline Mock & $33.44 \pm 3.29 c$ & 44.64 & $7.59 \pm 2.01 b$ & 27.99 & $3.23 \pm 0.51 b$ & 12.54 \\
\hline TMV & $23.12 \pm 5.21 \mathrm{~d}$ & - & $5.93 \pm 2.48 c$ & - & $2.87 \pm 0.64 c$ & - \\
\hline Th23 & $40.31 \pm 3.34 \mathrm{a}$ & 74.35 & $11.33 \pm 3.97 \mathrm{a}$ & 91.06 & $4.08 \pm 0.41 \mathrm{a}$ & 42.16 \\
\hline Th23 + TMV & $34.73 \pm 3.98 b$ & 50.22 & $7.54 \pm 1.98 \mathrm{~b}$ & 27.15 & $3.21 \pm 0.35 b$ & 11.85 \\
\hline
\end{tabular}

* SD, Standard deviation. The mean values in each of the columns that begin with the same letter are not statistically different $(p \leq 0.05)$.

Table 3. The effect of different treatments of Th23 and TMV inoculation on the length, fresh, and dry weights of the root system in tomato plants.

\begin{tabular}{ccccccc}
\hline \multirow{2}{*}{ Treatment } & \multicolumn{9}{c}{ Root \pm SD * } \\
\cline { 2 - 7 } & Length $(\mathbf{c m})$ & Increase (\%) & Fresh Weight (g) & Increase (\%) & Dry Weight (g) & Increase (\%) \\
\hline Mock & $11.41 \pm 0.63 \mathrm{c}$ & 16.91 & $4.11 \pm 0.45 \mathrm{c}$ & 34.75 & $2.03 \pm 0.63 \mathrm{~b}$ & 11.54 \\
TMV & $9.76 \pm 0.72 \mathrm{~d}$ & - & $3.05 \pm 0.34 \mathrm{~d}$ & - & $1.82 \pm 0.47 \mathrm{c}$ & - \\
Th23 & $19.04 \pm 2.14 \mathrm{a}$ & 95.08 & $5.94 \pm 1.19 \mathrm{a}$ & 94.75 & $2.64 \pm 0.51 \mathrm{a}$ & 45.05 \\
Th23 + TMV & $14.56 \pm 2.18 \mathrm{~b}$ & 49.18 & $4.75 \pm 1.23 \mathrm{~b}$ & 55.74 & $2.05 \pm 0.72 \mathrm{~b}$ & 12.64 \\
\hline
\end{tabular}

* SD, Standard deviation. The mean values in each of the columns that begin with the same letter are not statistically different $(p \leq 0.05)$. 
A significant difference in the total chlorophyll content of tomato leaves was observed in all treatments. The Th23 treatment exhibited the highest chlorophyll content (41.33 SPAD unit), followed by the mock treatment (35.89 SPAD unit), Th23 + TMV treatment (34.81 SPAD unit), and the TMV treatment (28.85 SPAD unit). Compared to the control (mock) treatment, the Th23 treatment showed a significant increase of $15.16 \%$, while TMV treatment exhibited a reduction in total chlorophyll by $24.40 \%$ in tomato leaves suffering from higher levels of mosaic and disease symptoms.

\subsection{Effect of Th23 Application on TMV Accumulation Level}

Regarding the accumulation levels of TMV particles inside the infected tissues, the Th23 + TMV treatment plants exhibited a significant decrease in the accumulation levels of TMV when compared to the TMV treatment plants. The TMV content was quantified based on the ratio of the cycle threshold $(\mathrm{Ct})$ value of the $T M V-C P$ gene to the tomato internal control actin gene. The qRT-PCR data showed that the accumulation level of TMV-CP of the TMV treatment was a 29.32-fold change, whereas it was 4.49-fold for the Th23 + TMV treatment plants. No TMV was detected in the mock or Th23 tomato plant treatments. Thus, the small amount of TMV detected in the Th23 pretreated plants-with a considerable reduction in viral accumulation level by $84.69 \%$-indicated that Th 23 could induce plant resistance to TMV proliferation in tomato tissues.

\subsection{Oxidative Stress Markers Assay}

Compared to mock treatment, the tomato plant leaves infected with TMV showed a significant increase in the content of $\mathrm{H}_{2} \mathrm{O}_{2}$ and MDA (Figure 3). For MDA, the TMV treatment exhibited the highest level $(312.23 \mu \mathrm{M} / \mathrm{g} \mathrm{FW})$ with a significant increase of $136.16 \%$ compared to the mock treatment of $132.21 \mu \mathrm{M} / \mathrm{g}$ FW. On the other hand, the tomato plants of two treatments, Th23 and Th23 + TMV, showed a considerable reduction in MDA content compared to the TMV treatment. The Th23 treatment recorded $169.46 \mu \mathrm{M} / \mathrm{g}$ FW while Th23 + TMV showed $184.73 \mu \mathrm{M} / \mathrm{g}$ FW (Figure 3A). Similar to MDA, $\mathrm{H}_{2} \mathrm{O}_{2}$ was significantly elevated upon TMV infection (Figure 3B). The TMV treatment showed the greatest $\mathrm{H}_{2} \mathrm{O}_{2}$ level $(10.09 \mu \mathrm{M} / \mathrm{g} F W)$, which exhibited a considerable increase of $153.52 \%$ compared to the control $(3.98 \mu \mathrm{M} / \mathrm{g} \mathrm{FW})$. On the other hand, the pretreatment of tomato plants with Th23 (Th23 + TMV treatment) recorded $6.91 \mu \mathrm{M} / \mathrm{g}$ FW with significant decreases in the $\mathrm{H}_{2} \mathrm{O}_{2}$ level by $31.52 \%$ compared to the nontreated tomato plants. Moreover, no significant difference between the Th23 treatment $(4.02 \mu \mathrm{M} / \mathrm{g} \mathrm{FW})$ and mock treatment plants was recorded (Figure 3B). 


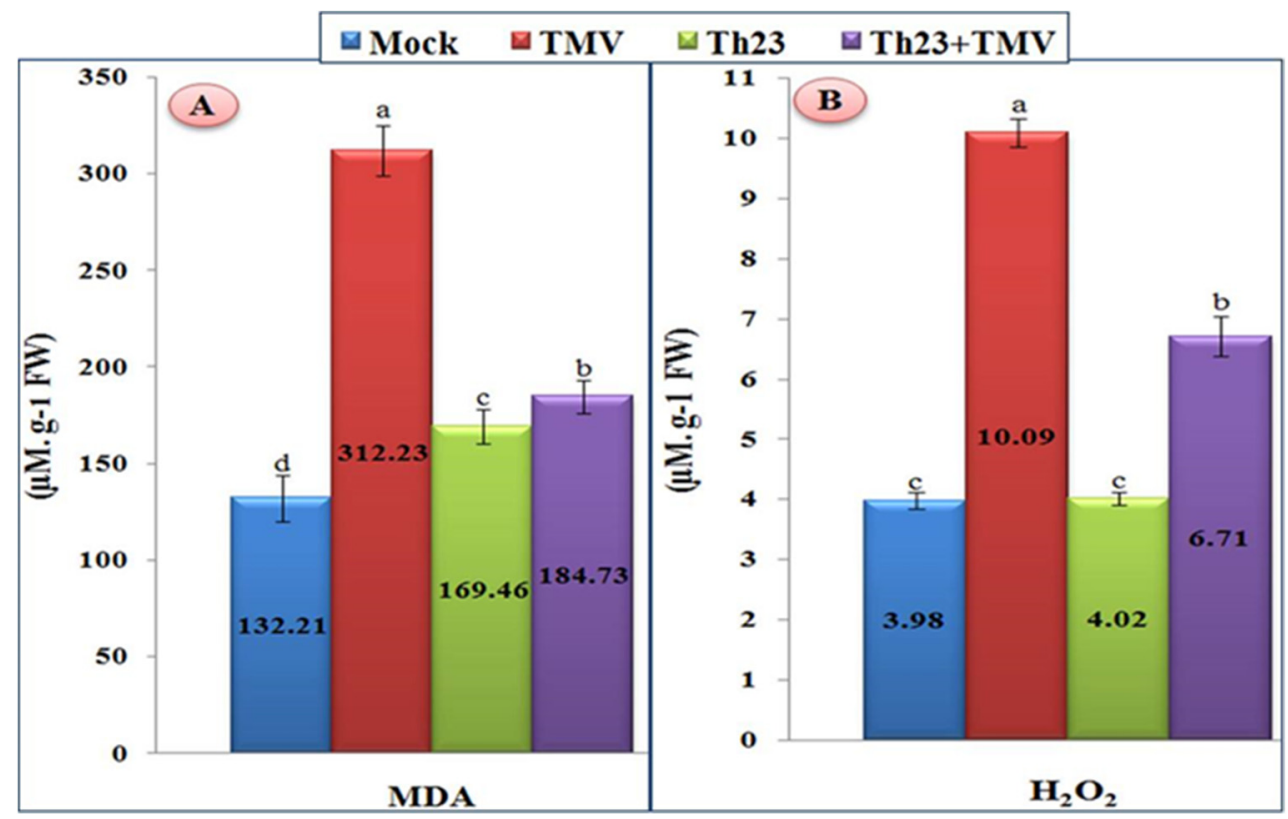

Figure 3. (A) Malondialdehyde content (MDA) and (B) hydrogen peroxide accumulation levels as affected by various treatments including untreated plants (mock), TMV-treated plants (TMV), Trichoderma hamatum strain Th23 application (Th23), and T. hamatum strain Th23 application $48 \mathrm{~h}$ before TMV inoculation (Th23 + TMV). The mean values in each of the columns that begin with the same letter are not statistically different $(p \leq 0.05)$.

\subsection{Antioxidant Enzymes Activity}

The three antioxidant enzymes, catalase (CAT), polyphenol oxidase (PPO), and superoxide dismutase (SOD), were clearly differentiated upon TMV infection and Th23 treatments (Figure 4). Most importantly, Th23 treatment induced an antioxidant defense system and significantly increased the three-enzyme content inside tomato leaves. For PPO activity, the Th23 treatment exhibited the highest level $(0.31 \mu \mathrm{M} / \mathrm{g} \mathrm{FW})$, with an increase in its activity of $138.46 \%$ and $210 \%$ when compared to the mock treatment $(0.13 \mu \mathrm{M} / \mathrm{g} \mathrm{FW})$ and TMV treatment $(0.10 \mu \mathrm{M} / \mathrm{g} \mathrm{FW})$, respectively. Similarly, the Th23 + TMV treatment induced the PPO activity $(0.19 \mu \mathrm{M} / \mathrm{g}$ FW) with significant increases of $46.15 \%$ and $90 \%$ compared to the mock and TMV treatments, respectively (Figure 4). Regarding antioxidant enzyme CAT activity, the Th23-pretreated tomato plants showed the greatest level of content $(0.57 \mu \mathrm{M} / \mathrm{g}$ FW) with a significant increase of $67.65 \%$ and $21.27 \%$ compared to TMV and mock treatments, respectively (Figure 4). In addition, Th23 + TMV treatment exhibited $0.46 \mu \mathrm{M} / \mathrm{g}$ FW activity with an increase of $35.29 \%$ compared to then nontreated plants. Compared to the mock treatment $(0.47 \mu \mathrm{M} / \mathrm{g} \mathrm{FW})$, no significant change $(p \leq 0.05)$ was reported with Th23 + TMV treatment (Figure 4). Concerning SOD activity, the results showed that the SOD level content was considerably decreased upon TMV infection. The TMV treatment was significantly reduced by $27.88 \%$ compared to the control $(0.45 \mu \mathrm{M} / \mathrm{g}$ FW). Although there was a slight reduction in SOD activity of Th23 + TMV treatment $(0.43 \mu \mathrm{M} / \mathrm{g} \mathrm{FW})$, no significant difference was reported compared with the control. The Th23 treatment showed the highest SOD activity $(0.59 \mu \mathrm{M} / \mathrm{g}$ FW $)$ with significant increases of $84.38 \%$ and $31.11 \%$ compared to the TMV and mock treatments, respectively (Figure 4 ). 


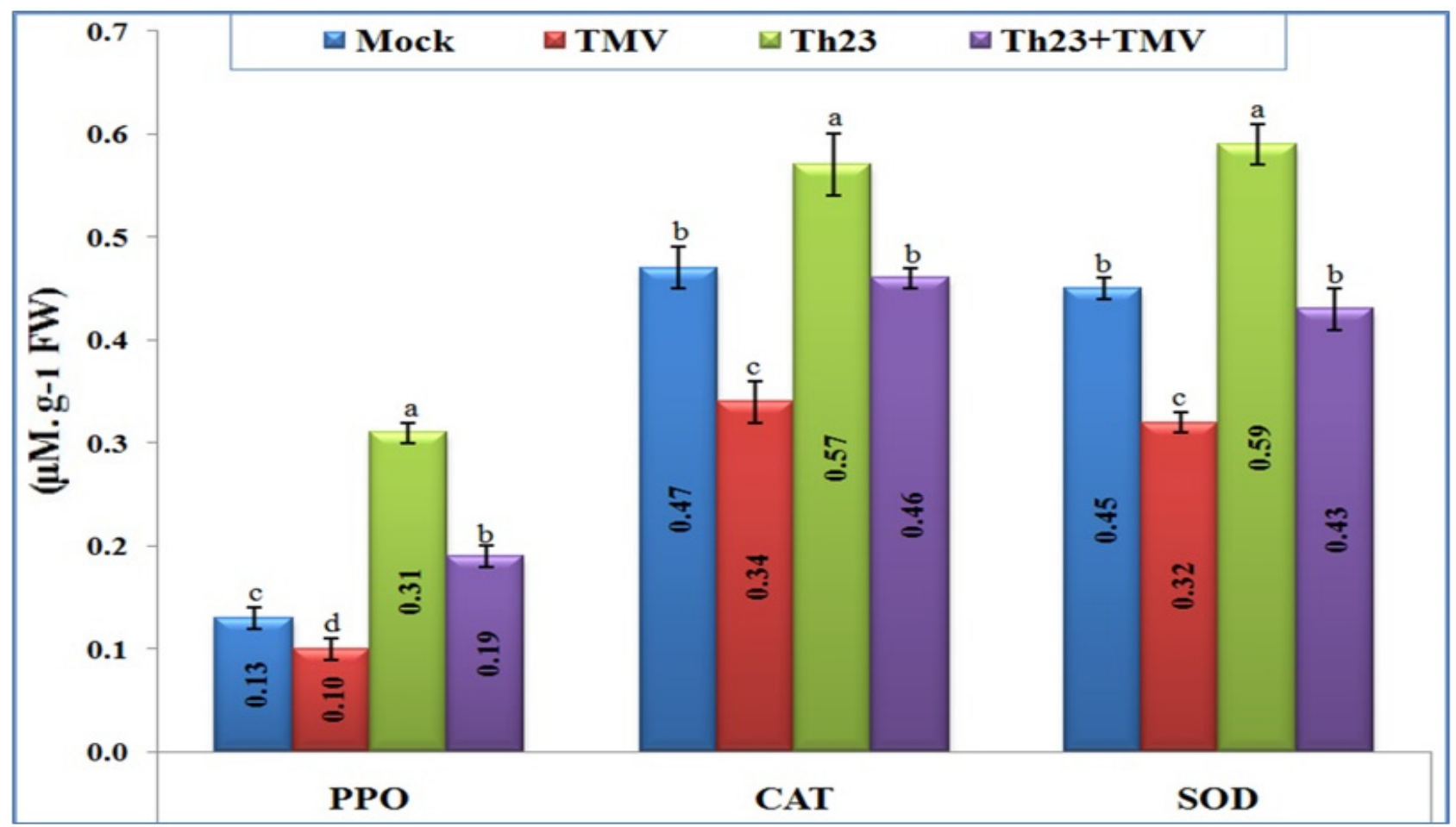

Figure 4. Polyphenol oxidase (PPO), catalase (CAT), and sodium dismutase (SOD) kinetic levels as affected by various treatments including untreated plants (mock), TMV-treated plants (TMV), Trichoderma hamatum strain Th23 application (Th23), and T. hamatum strain Th23 application $48 \mathrm{~h}$ before TMV inoculation (Th23 + TMV). The mean values in each of the columns that begin with the same letter are not statistically different $(p \leq 0.05)$.

\subsection{Transcriptional Levels of Defense-Related Genes 3.6.1. Polyphenolic Biosynthetic Pathway}

The qRT-PCR results showed significant increases $(p \leq 0.05)$ in the relative expression levels of the two polyphenolic biosynthetic pathway genes, HQT and CHS, in the Th23-treated tomato plants, either challenged with TMV or not (Figure 5). The Th23 treatment recorded the highest transcript of $H Q T$ with a relative transcriptional level of 3.69-fold change higher than the mock treatment plants. Similarly, a significant increase with a relative transcriptional level of 2.82-fold change greater than the control was reported in the Th23 + TMV treatment tomato plants. No significant difference was noted between the TMV treatment and control (Figure 5). Regarding the CHS transcript, it was reported that TMV treatment suppressed and significantly downregulated CHS in tomato plant tissues. Intriguingly, the application of Th23 induced CHS transcripts in Th23 and Th23 + TMV treatments. The Th23 treatment exhibited the highest relative transcriptional level (2.16-fold), followed by the Th23 + TMV treatment with a 1.29-fold change higher than the mock treatment. The TMV treatment showed a relative expression level of 0.79 -fold lower than mock treatment plants (Figure 5). 


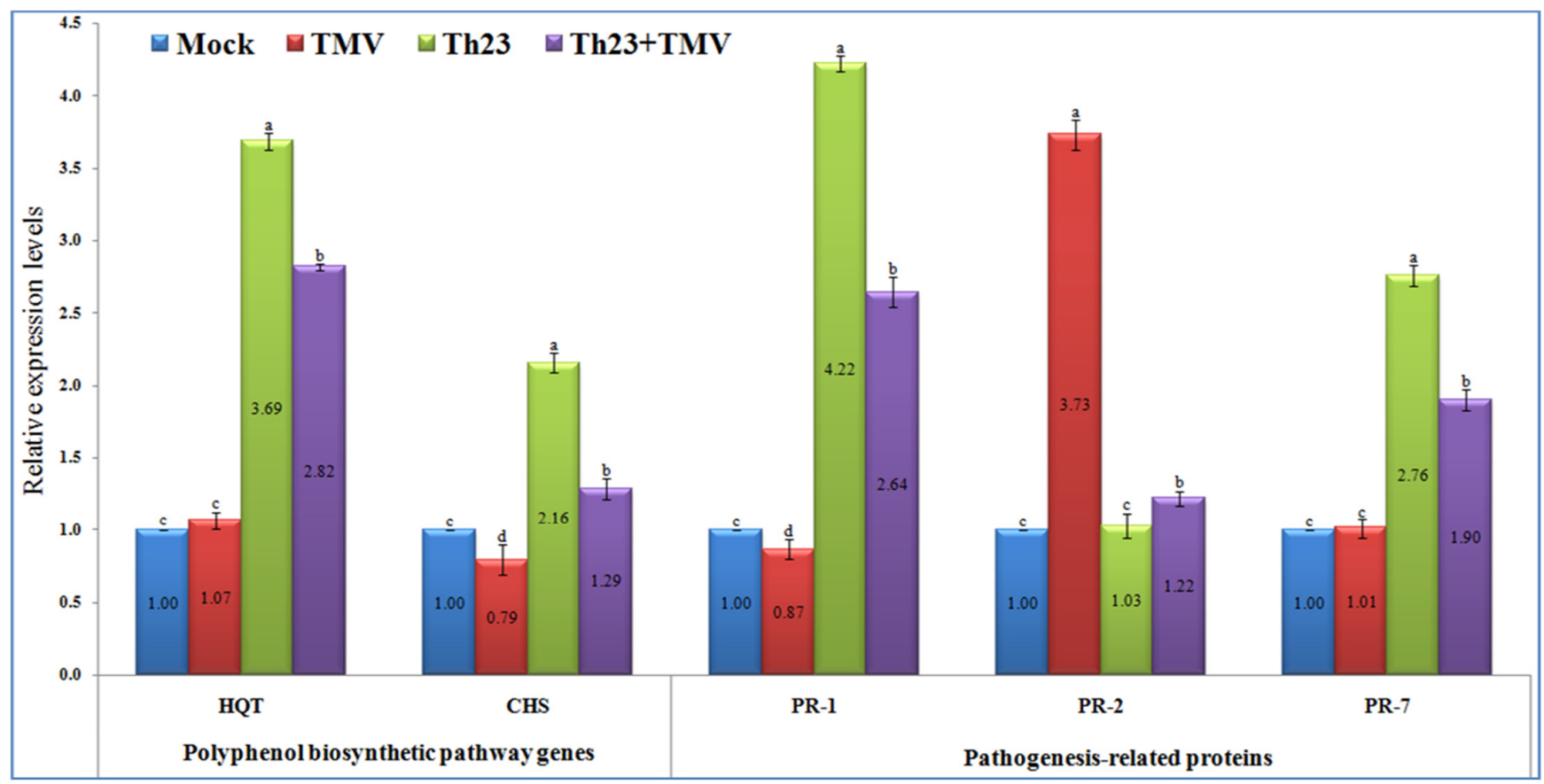

Figure 5. Polyphenol biosynthetic pathway genes (HQT and $C H S$ ) and pathogenesis-related proteins $(P R-1, P R-2$, and $P R-7)$ relative expression levels quantified by $\mathrm{qRT}-\mathrm{PCR}$ as affected by various treatments including untreated plants (mock), TMV-treated plants (TMV), Trichoderma hamatum strain Th23 application (Th23), and T. hamatum strain Th23 application $48 \mathrm{~h}$ before TMV inoculation $($ Th23 + TMV). The mean values in each of the columns that begin with the same letter are not statistically different $(p \leq 0.05)$.

\subsubsection{Pathogenesis-Related Proteins}

In the present study, the three pathogenesis-related proteins ( $P R-1, P R-2$, and $P R-7)$ were significantly differentiated upon challenging tomato plants with Th23 and/or TMV infection (Figure 5). For $P R-1$, it was shown that the treatment of tomato plants with Th23 isolate, either alone or before TMV infection, triggered the expression of the PR-1 gene. The Th23 treatment showed a relative expression level of 4.22-fold change higher than the control, which revealed a significant increase of $385.06 \%$ compared to the TMV treatment. Furthermore, Th $23+$ TMV treatment induced $P R-1$ with a relative expression level of 2.64-fold change higher than the mock treatment. The nontreated tomato plants challenged with TMV only exhibited a significant $(p \leq 0.05)$ decreasing $P R-1$ level, with a relative expression level of 0.87 -fold change lower than the control (Figure 5). Regarding the $P R-2$ transcript profile, it was reported that the TMV infection considerably induced $P R-2$ in the infected tomato tissues with a relative expression level of 3.73-fold higher than the mock treatment. The Th23 + TMV treatment exhibited a slight upregulation with a relative transcriptional level of 1.22 -fold higher than the control. Among the Th23 and mock treatments, no significant change was reported (Figure 5). Concerning PR-7, the treatment of tomato plants with the Th23 isolate significantly induced the expression of $P R-7$. The Th23 treatment exhibited the highest expression level (2.76-fold), while the Th23 + TMV treatment showed a relative transcriptional level of 1.90-fold higher than the mock treatment. On the other hand, no significant difference was observed in the TMV treatment compared to the mock treatment at $p \leq 0.05$ (Figure 5).

\section{Discussion}

Plant diseases, particularly plant viral infestations, are responsible for significant crop losses, and pose a serious threat to food security all over the world [48]. Due to the difficult problem of their control and their changing environmental conditions, it is 
urgently necessary to discover and identify new biocontrol agents capable of controlling plant viral infections. The use of plant growth-promoting microorganisms as biocontrol agents is a safe alternative to the harmful use of chemicals and is seen as a long-term and environmentally friendly alternative [45]. There are, to date, few studies on the role of Trichoderma spp. in the induction of plant defenses against viral infections. The majority of prior research has spotlighted the critical role of Trichoderma spp. in the management of plant-fungal and bacterial diseases. Due to the increasing number of species and the paucity of morphological characteristics, it is very difficult to differentiate Trichoderma species using morphological characteristics $[49,50]$. Sequences of the most variable regions of specific genes are now becoming increasingly useful in identifying closely related species. In the current study, the ITS (Acc\# MW797032) sequencing BLAST and phylogenetic tree results were not sufficient for species delimitation of the isolated Trichoderma strain. It was reported that the analysis based on ITS sequences has been shown to be ineffective in distinguishing closely related species within Trichoderma species complexes [51]. The gene sequences of tef1 and $r p b 2$ genes are very informative and have been shown to be useful in investigating closely related strains at the species level [50,52]. As a result, the tef1 and rpb2 genes have become the preferred markers for identifying Trichoderma strains [53]. Based on the NCBI-BLAST alignment and phylogenetic tree analysis of rpb2 (Acc\# OL412667) and tef1 (Acc\# OL439486) genes, the isolated Trichoderma strain was identified as Trichoderma hamatum strain Th23.

Under greenhouse conditions, the soil application of the Th23 isolate, either alone or $48 \mathrm{~h}$ before TMV infection, significantly $(p \leq 0.05)$ enhanced the growth of tomato plants as well as chlorophyll content. At $15 \mathrm{dpi}$, the Th23 treatment exhibited the highest growth parameter values, followed by the Th 23 + TMV treatment. On the other hand, the TMV treatment showed a significantly negative impact on the growth of tomato plants at all the growth parameters. Several authors have shown that the application of Trichoderma spp. was associated with an increase in root length, shoot length, and dry weight compared to the control plants $[9,54-56]$. Generally, the severe morphological and physiological changes including mosaic symptoms that occur upon viral infection are linked to changes in chlorophyll content and result in reduced photosynthesis [21,57]. Thus, the changes in chlorophyll pigment content upon viral infection can be used to indicate the functional status of photosynthesis in plants [58]. In the current study, the analysis of chlorophyll content showed that Th23 and Th23 + TMV treatments resulted in significant changes in chlorophyll content compared to tomato leaves of the TMV treatment. These results were in agreement with the findings of other researchers who showed that the application of Trichoderma spp. increased the chlorophyll content of the treated plants [59,60], while chlorophyll reduction was associated with a viral infection $[57,58]$. Consequently, the application of Th23 strain can boost photosynthetic rates and efficiency in plants [10], primarily through enhancing the plant's redox state [61]. The current findings confirmed that Th23 can protect tomato plants against TMV not only by modulating symptoms and thus reducing disease severity, but also by lowering viral accumulation inside plant tissues. The observation of symptoms as well as the severity of the disease demonstrated that Th23 treatment reduced TMV in all treated plants. On the other hand, the significant decrease in TMV accumulation level (84.69\%) confirmed the protective efficacy of Th23 against TMV infestation. Thus, the obtained data suggest that Th23 could stimulate the host's innate immune system and/or trigger SAR, resulting in TMV suppression and/or replication inhibition. The findings were consistent with those of Tamandegani et al. [57], who reported that the pretreatment of soils with T. asperellum was associated with a significant reduction in CMV accumulation levels when compared with the untreated control cucumber plants. It was reported that Trichoderma-induced resistance to viral infection was usually associated with a reduction in virus concentration and disease severity, indicating that different defensive pathways were implicated $[6,57,62]$. The obtained results were consistent with the reported protective activities of different Trichoderma spp. against various plant viral 
infestations. It was shown that pretreating plants with Trichoderma spp. resulted in a considerable reduction in viral accumulation compared to nontreated plants $[15,57,62]$.

Oxidative burst accumulation is one of the first reactions in the plant defense system. Reactive oxygen species (ROS) regulate various cellular processes including antimicrobial activity and the regulation of certain plant transcription factors [63]. One of the ROS molecules belonging to nonradical oxidants is hydrogen peroxide $\left(\mathrm{H}_{2} \mathrm{O}_{2}\right)$. In plantpathogen interactions, $\mathrm{H}_{2} \mathrm{O}_{2}$ serves various functions including inhibition of pathogen propagation, affects the defense system, and is a SAR signal molecule [64]. In the current study, $\mathrm{H}_{2} \mathrm{O}_{2}$ levels in the TMV treatment were 2.53 times higher than in the mock treatment plants. The same findings were obtained in a study on CMV reported by Song et al. [65], who noticed CMV enhanced $\mathrm{H}_{2} \mathrm{O}_{2}$ buildup in tomato and cucumber chloroplasts and mitochondria. Additionally, a study by Sorahinobar et al. [66] reported that $\mathrm{H}_{2} \mathrm{O}_{2}$ builds up fast once the virus infects the host, increasing resistance. At the same time, $\mathrm{H}_{2} \mathrm{O}_{2}$ levels were decreased in the Th23 + TMV treatment compared to the TMV treatment. This decrease may have been due to the protective activity of Th23 and a reduction in the TMV accumulation inside the treated tomato tissues. This result was similar to the findings of Luo et al. [67], who noticed that CMV $+T$. asperellum decreased the damaging effects of ROS in cucumber; thus, one probable mechanism of T. asperellum-induced CMV resistance is the stimulation of early plant defense mechanisms. Regarding the MDA level, the TMV treatment showed 2.36 times higher MDA levels compared to the controls. MDA accumulation had a limited significant increase in Th23 and Th23 + TMV treatments (169.46 and $184.73 \mu \mathrm{M} / \mathrm{g} \mathrm{FW}$, respectively) compared to the control $(132.21 \mu \mathrm{M} / \mathrm{g} \mathrm{FW})$. These findings were consistent with those of Sobhy et al. [68] and Loreto and Velikova [69]. They suggested that an increase in MDA could indicate that plants are under oxidative stress, and thus could be a promising biomarker of membrane breakdown in pathogen-infected plants. Similar results were reported by Anthony et al. [70] in bananas infected with Fusarium fungus.

It is well known that CAT protects plant cells under stress exposure from ROS oxidative damage by converting ROS components to less toxic and more stable molecules such as oxygen and water [71,72]. In our study, the CAT enzyme decreased in tomato plants inoculated with TMV compared with the control, while it significantly increased in tomato plants treated with Th23 alone and Th23 + TMV. It seems that the preapplication of Th23 before TMV inoculation normalizes and cures the plant from TMV infection and keeps the accumulation levels of the CAT enzyme in normal conditions compared with the control plants. It has been proposed that CAT increases cell wall resistance, induces defense genes, accumulates SA signal, and suppresses RNA silencing [73]. The CAT enzyme may interact with viral movement protein, which is involved in symptom induction such as the CMV $2 \mathrm{~b}$ protein reported by Mathioudakis et al. [74]. Likewise, the enhanced synthesis of antioxidant enzymes such as SOD and PPO in infected tomato plant leaves counteracted the higher MDA and $\mathrm{H}_{2} \mathrm{O}_{2}$ levels, limiting tissue oxidation [72,75] as well as limiting pathogen invasion by reinforcing cell walls [76]. Such antioxidant enzymes were significantly higher in plants that interacted with pathogens following exposure to the biocontrol agent such as Trichoderma spp., which triggers the induced systematic resistance by secreting defense-related enzymes including $\mathrm{PPO}$, against viral pathogens, according to previous studies $[57,77,78]$. In our investigation, tomato plant inoculation with TMV alone caused a significant decrease in PPO and SOD activity. In contrast, in plants treated with Th23 only or with Th23 + TMV, both PPO and SOD enzyme activities reached their maximum levels. This change suggested that these enzymes could play a crucial role in ROS detoxification. Thus, the Th23 strain could activate PPO and SOD to prevent the tomato plant cells from TMV multiplication and transmission by establishing polymerized phenolic barriers around infection sites to kill the pathogen $[79,80]$.

The expression of hundreds of genes is triggered by the plant-virus interaction. It was reported that plant defensive responses were regulated by crosstalk between the SA, JA, and ET signaling pathways [81]. 
The qRT-PCR results showed that the relative expression levels of the two polyphenolic biosynthesis pathway genes, HQT and CHS, were significantly increased in Th23-treated tomato plants, whether challenged with TMV or not. CHS, the first enzyme in the flavonoid pathway, transforms $p$-coumaroyl CoA into naringenin chalcones and is regarded as a key precursor necessary for plant flavonoids $[35,44]$. HQT is a principal enzyme in the biosynthesis of chlorogenic acid, catalyzing the conversion of caffeoyl-CoA and quinic acid to chlorogenic acid [82]. Chlorogenic acid is a polyphenolic compound that is important in improving plant resistance and inhibiting pathogens such as viruses [83,84]. In the current investigation, the Th23 treatment had the greatest transcript of $H Q T$ with a relative transcriptional level 3.69-fold greater than the mock-treated plants. Similarly, with the Th23 + TMV treatment, tomato plants showed a substantial rise, with a relative expression level 2.82-fold higher than the control. In terms of the CHS transcript, it has been demonstrated that TMV infection significantly decreased CHS expression in tomato plant tissues after TMV treatment. Surprisingly, the application of Th23 induced CHS transcripts in Th23 and Th 23 + TMV treatments. It was reported that the roots invaded by T. harzianum demonstrated great resistance against dangerous organisms, which was connected with changes in phenolic accumulation by Yedidia et al. [85]. Consequently, phenolics accumulating in Trichoderma-treated plants can act as electron and hydrogen donors, protecting plant tissue from oxidative damage during pathogen infection [86]. Previous research has found that overexpression of CHS could result in a large accumulation of flavonoid and isoflavonoid compounds with broad antimicrobial activity against a wide range of phytopathogens [87-90]. Additionally, it was reported that increases in chlorogenic acid levels were linked to increased $H Q T$ expression and vice versa $[82,88]$. Thus, the elevation of transcriptional expression of these genes demonstrates their antiviral role, implying that the tomato plant can utilize polyphenolic compounds as one of its defenses against viral infection and spread. In line with the obtained results, the increased expression levels of CHS and HQT resulted in the accumulation of polyphenolic compounds inside plant tissues, the development of SAR, and increased resistance against TMV infestation [21]. As a result, pretreating tomato plants with Th23 may result in an increase in numerous flavonoid compounds. Thus, Th23 might be used to combat TMV infections as a biocontrol agent. However, further study is needed for future field uses.

Several reports have proposed that a convergent collection of PR proteins is responsible for SAR development and is effective in suppressing pathogen multiplication and/or dissemination [21,91,92]. For $P R-1$, it was shown that the TMV treatment exhibited a significant decrease in $P R-1$ expression level by 0.77 -fold lower than the control at $p \leq 0.05$. On the other hand, the Th23 treatment or Th 23 + TMV treatment triggered the expression level of $P R-1$ with significant increases of $385.06 \%$ and $203.45 \%$, respectively, when compared with the TMV treatment. Salicylic acid (SA) is a well-known plant signal phytohormone molecule, and its role in plant immune activation has been documented for more than two decades $[20,93,94]$. Furthermore, several studies have shown that $P R-1$ is an SA marker gene, an important regulator of SAR, and a predictor of early plant defensive response $[93,95]$. Meanwhile, induction of $P R-1$ is frequently associated with SA accumulation, which results in SAR activation $[20,96,97]$. As a result, we hypothesized that Th23 may produce elicitor metabolite compounds that induce systemic resistance, activating SAR, and enhancing plant resistance to viral infection. $P R-7$, the most prominent $P R$ gene in tomato plant tissues, encodes endoproteinase activity in plants. It has emerged as a major component of plant defensive response proteins against various pathogens [91,98-100]. In this study, the Th23 treatment had the highest expression level, followed by Th23 + TMV treatment, with a relative transcriptional level 2.76- and 1.90-fold higher than the mock treatment, respectively. It was postulated that $P R-7$ participated in pathogen perception and signaling cascade activation in infected tomato plants via specialized processing of a LRP (leucine-rich repeat protein) $[101,102]$. However, more characterization and functional analysis of $P R-7$ will lead to a more in-depth understanding of its role in plant-viral interactions. 
In addition to their primary role in viral transport from cell to cell, $P R-2$ encoding -1,3-glucanases mediate cell-to-cell communication and long-distance signaling by limiting callose deposition near plasmodesmata [103-105]. They are involved in pathogenic defense and several physiological plant activities and are primarily induced by SAR and SAR inducers such as SA $[37,106,107]$. In the current study, TMV infection considerably induced $P R-2$ in the TMV treatment with a relative transcriptional level 3.73-fold higher than in the mock treatment. The findings were consistent with previous research that revealed significant activation of $P R-2$ in response to viral infections in a variety of plant species including Arabidopsis, tobacco, potato, and tomato [37,108-111]. Moreover, a lack of tobacco $P R-2$ expression was associated with lower viral infection susceptibility [111], whereas overexpression accelerated PVY infection spread across cells [112,113]. Interestingly, treatments of tomato plants with Th23 prior to TMV infection showed a slight increase in $P R-2$ compared to the control plants. There were no significant changes reported between Th23 and mock treatments in tomato plants at $p \leq 0.05$. Thus, the preapplication of Th23 before viral infection may reduce TMV infection by lowering $P R-2$ expression and inhibiting long-distance viral movement between cells.

\section{Conclusions}

In this study, we investigated, for the first time, the effects of Trichoderma hamatum Th23 in tomato plants as a safeguard against TMV. Th23 can induce tomato systemic resistance against TMV by modulating the plant response, triggering multiple plant defense pathways, increasing resistance, and preventing the suppression of defense genes. The preapplication of Th23 before TMV infection significantly enhanced tomato growth parameter heights, improved total chlorophyll, decreased disease severity, and reduced TMV accumulation inside infected tissues. Moreover, a reduction in oxidative stress markers (MDA and $\mathrm{H}_{2} \mathrm{O}_{2}$ ) and elevation of the antioxidant enzymes (SOD, CAT, and PPO) were also reported. In addition, the triggering of transcriptional levels of $H Q T, C H S, P R-1$, and $P R-7$ was observed. The results implied the potential of Th23 application in plant viral disease control.

Author Contributions: Conceptualization, A.A., A.A.A.-A., A.A.A. and S.I.B.; Methodology, A.A., A.A.A., A.A.A.-A. and S.I.B.; Software, A.A. and S.I.B.; Formal analysis, A.A.; Investigation, A.A. and S.I.B.; Writing—original draft preparation, A.A., A.A.A., A.A.A.-A. and S.I.B.; Writing-review and editing, A.A., S.I.B. and A.A.A.-A.; Funding acquisition, A.A.A.-A. All authors have read and agreed to the published version of the manuscript.

Funding: This research was financially supported by the Researchers Supporting Project number (RSP2022R505), King Saud University, Riyadh, Saudi Arabia.

Institutional Review Board Statement: Not applicable.

Informed Consent Statement: Not applicable.

Data Availability Statement: All data reported here are available from the authors upon request.

Acknowledgments: The authors would like to extend their appreciation to the Researchers Supporting Project number (RSP2022R505), King Saud University, Riyadh, Saudi Arabia.

Conflicts of Interest: The authors declare no conflict of interest.

\section{References}

1. Ge, Y.-H.; Liu, K.-X.; Zhang, J.-X.; Mu, S.-Z.; Hao, X.-J. The Limonoids and Their Antitobacco Mosaic Virus (TMV) Activities from Munronia unifoliolata Oliv. J. Agric. Food Chem. 2012, 60, 4289-4295. [CrossRef]

2. Abdelkhalek, A.; Sanan-Mishra, N. A comparative analysis of the suppressor activity of Tobacco mosaic virus proteins in the tomato plant. Jordan J. Biol. Sci. 2018, 11, 469-473.

3. Scholthof, K.-B.G.; Adkins, S.; Czosnek, H.; Palukaitis, P.; Jacquot, E.; Hohn, T.; Hohn, B.; Saunders, K.; Candresse, T.; Ahlquist, P.; et al. Top 10 plant viruses in molecular plant pathology. Mol. Plant Pathol. 2011, 12, 938-954. [CrossRef] [PubMed]

4. Ara, I.; Bukhari, N.A.; Aref, N.M.; Shinwari, M.M.A.; Bakir, M.A. Antiviral activities of streptomycetes against tobacco mosaic virus (TMV) in Datura plant: Evaluation of different organic compounds in their metabolites. Afr. J. Biotechnol. 2012, 11, 2130-2138. 
5. Elsharkawy, M.M. Induced systemic resistance against Cucumber mosaic virus by Phoma sp. GS8-2 stimulates transcription of pathogenesis-related genes in Arabidopsis. Pest Manag. Sci. 2019, 75, 859-866. [CrossRef] [PubMed]

6. Elsharkawy, M.M.; Shimizu, M.; Takahashi, H.; Ozaki, K.; Hyakumachi, M. Induction of systemic resistance against Cucumber mosaic virus in Arabidopsis thaliana by Trichoderma asperellum SKT-1. Plant Pathol. J. 2013, 29, 193. [CrossRef] [PubMed]

7. Benítez, T.; Rincón, A.M.; Limón, M.C.; Codón, A.C. Biocontrol mechanisms of Trichoderma strains. Int. Microbiol. 2004, 7, 249-260. [PubMed]

8. Harman, G.E. Overview of Mechanisms and Uses of Trichoderma spp. Phytopathology 2006, 96, 190-194. [CrossRef]

9. Harman, G.E.; Howell, C.R.; Viterbo, A.; Chet, I.; Lorito, M. Trichoderma species-Opportunistic, avirulent plant symbionts. Nat. Rev. Microbiol. 2004, 2, 43-56. [CrossRef]

10. Shoresh, M.; Harman, G.E.; Mastouri, F. Induced Systemic Resistance and Plant Responses to Fungal Biocontrol Agents. Annu. Rev. Phytopathol. 2010, 48, 21-43. [CrossRef]

11. Mathys, J.; De Cremer, K.; Timmermans, P.; Van Kerckhove, S.; Lievens, B.; Vanhaecke, M.; Cammue, B.P.A.; De Coninck, B. Genome-Wide Characterization of ISR Induced in Arabidopsis thaliana by Trichoderma hamatum T382 Against Botrytis cinerea Infection. Front. Plant Sci. 2012, 3, 108. [CrossRef] [PubMed]

12. Alfano, G.; Ivey, M.L.L.; Cakir, C.; Bos, J.I.B.; Miller, S.A.; Madden, L.; Kamoun, S.; Hoitink, H.A.J. Systemic Modulation of Gene Expression in Tomato by Trichoderma hamatum 382. Phytopathology 2007, 97, 429-437. [CrossRef] [PubMed]

13. Mastouri, F.; Björkman, T.; Harman, G.E. Seed treatment with Trichoderma harzianum alleviates biotic, abiotic, and physiological stresses in germinating seeds and seedlings. Phytopathology 2010, 100, 1213-1221. [CrossRef] [PubMed]

14. Harman, G.E.; Herrera-Estrella, A.H.; Horwitz, B.A.; Lorito, M. Trichoderma-From basic biology to biotechnology. Microbiology 2012, 158, 1-2. [CrossRef] [PubMed]

15. Vitti, A.; La Monaca, E.; Sofo, A.; Scopa, A.; Cuypers, A.; Nuzzaci, M. Beneficial effects of Trichoderma harzianum T-22 in tomato seedlings infected by Cucumber mosaic virus (CMV). BioControl 2014, 60, 135-147. [CrossRef]

16. Bari, R.; Jones, J.D.G. Role of plant hormones in plant defence responses. Plant Mol. Biol. 2008, 69, 473-488. [CrossRef]

17. Vitti, A.; Nuzzaci, M.; Scopa, A.; Tataranni, G.; Remans, T.; Vangronsveld, J.; Sofo, A. Auxin and Cytokinin Metabolism and Root Morphological Modifications in Arabidopsis thaliana Seedlings Infected with Cucumber mosaic virus (CMV) or Exposed to Cadmium. Int. J. Mol. Sci. 2013, 14, 6889-6902. [CrossRef]

18. Ali, S.; Ganai, B.A.; Kamili, A.N.; Bhat, A.A.; Mir, Z.A.; Bhat, J.A.; Tyagi, A.; Islam, S.T.; Mushtaq, M.; Yadav, P. Patho-genesisrelated proteins and peptides as promising tools for engineering plants with multiple stress tolerance. Microbiol. Res. 2018, 212, 29-37. [CrossRef]

19. Singh, N.; Pandey, P.; Dubey, R.; Maheshwari, D.K. Biological control of root rot fungus Macrophomina phaseolina and growth enhancement of Pinus roxburghii (Sarg.) by rhizosphere competent Bacillus subtilis BN1. World J. Microbiol. Biotechnol. 2008, 24, 1669-1679. [CrossRef]

20. Dempsey, D.A.; Vlot, A.C.; Wildermuth, M.C.; Klessig, D.F. Salicylic Acid Biosynthesis and Metabolism. Arab. Book 2011, 9 , e0156. [CrossRef]

21. Abdelkhalek, A.; Al-Askar, A.A.; Alsubaie, M.M.; Behiry, S.I. First Report of Protective Activity of Paronychia argentea Extract against Tobacco Mosaic Virus Infection. Plants 2021, 10, 2435. [CrossRef] [PubMed]

22. Akyol, H.; Riciputi, Y.; Capanoglu, E.; Caboni, M.F.; Verardo, V. Phenolic Compounds in the Potato and Its Byproducts: An Overview. Int. J. Mol. Sci. 2016, 17, 835. [CrossRef] [PubMed]

23. Shoresh, M.; Harman, G.E. Differential expression of maize chitinases in the presence or absence of Trichoderma harzianum strain T22 and indications of a novel exo- endo-heterodimeric chitinase activity. BMC Plant Biol. 2010, 10, 1-11. [CrossRef] [PubMed]

24. Contreras-Cornejo, H.A.; Macías-Rodríguez, L.; Cortés-Penagos, C.; López-Bucio, J. Trichoderma virens, a plant beneficial fungus, enhances biomass production and promotes lateral root growth through an auxin-dependent mechanism in Arabidopsis. Plant Physiol. 2009, 149, 1579-1592. [CrossRef] [PubMed]

25. Hermosa, R.; Rubio, M.B.; Cardoza, R.E.; Nicolás, C.; Monte, E.; Gutiérrez, S. The contribution of Trichoderma to balancing the costs of plant growth and defense. Int. Microbiol. 2013, 16, 69-80.

26. Mukherjee, P.K.; Horwitz, B.A.; Herrera-Estrella, A.; Schmoll, M.; Kenerley, C.M. Trichoderma Research in the Genome Era. Annu. Rev. Phytopathol. 2013, 51, 105-129. [CrossRef]

27. Siddaiah, C.N.; Satyanarayana, N.R.; Mudili, V.; Gupta, V.K.; Gurunathan, S.; Rangappa, S.; Huntrike, S.S.; Srivastava, R.K. Elicitation of resistance and associated defense responses in Trichoderma hamatum induced protection against pearl millet downy mildew pathogen. Sci. Rep. 2017, 7, 43991. [CrossRef]

28. Zin, N.A.; Badaluddin, N.A. Biological functions of Trichoderma spp. for agriculture applications. Ann. Agric. Sci. 2020, 65, 168-178. [CrossRef]

29. Elad, Y.; Chet, I.; Henis, Y. A selective medium for improving quantitative isolation of Trichoderma spp. from soil. Phytoparasitica 1981, 9, 59-67. [CrossRef]

30. White, T.J.; Bruns, T.; Lee, S.; Taylor, J.W. Amplification and direct sequencing of fungal ribosomal RNA genes for phylogenetics In PCR Protocols: A Guide to Methods and Applications; Innis, M.A., Gelfand, D.H., Sninsky, J.J., White, T.J., Eds.; Academic Press: Cambridge, MA, USA, 1990; Volume 18, pp. 315-322.

31. Liu, Y.J.; Whelen, S.; Hall, B.D. Phylogenetic relationships among ascomycetes: Evidence from an RNA polymerse II subunit. Mol. Biol. Evol. 1999, 16, 1799-1808. [CrossRef] 
32. Hatvani, L.; Antal, Z.; Manczinger, L.; Szekeres, A.; Druzhinina, I.S.; Kubicek, C.P.; Nagy, A.; Nagy, E.; Vágvölgyi, C.; Kredics, L. Green mold diseases of Agaricus and Pleurotus spp. are caused by related but phylogenetically different Trichoderma species. Phytopathology 2007, 97, 532-537. [CrossRef] [PubMed]

33. Zhao, L.; Dong, J.; Hu, Z.; Li, S.; Su, X.; Zhang, J.; Yin, Y.; Xu, T.; Zhang, Z.; Chen, H. Anti-TMV activity and functional mechanisms of two sesquiterpenoids isolated from Tithonia diversifolia. Pestic. Biochem. Physiol. 2017, 140, 24-29. [CrossRef] [PubMed]

34. Kavroulakis, N.; Ehaliotis, C.; Ntougias, S.; Zervakis, G.; Papadopoulou, K.K. Local and systemic resistance against fungal pathogens of tomato plants elicited by a compost derived from agricultural residues. Physiol. Mol. Plant Pathol. 2005, 66, 163-174. [CrossRef]

35. André, C.M.; Schafleitner, R.; Legay, S.; Lefèvre, I.; Aliaga, C.A.A.; Nomberto, G.; Hoffmann, L.; Hausman, J.-F.; Larondelle, Y.; Evers, D. Gene expression changes related to the production of phenolic compounds in potato tubers grown under drought stress. Phytochemistry 2009, 70, 1107-1116. [CrossRef]

36. Sagi, M.; Davydov, O.; Orazova, S.; Yesbergenova, Z.; Ophir, R.; Stratmann, J.W.; Fluhr, R. Plant Respiratory Burst Oxidase Homologs Impinge on Wound Responsiveness and Development in Lycopersicon esculentum [W]. Plant Cell 2004, 16, 616-628. [CrossRef]

37. Abdelkhalek, A. Expression of tomato pathogenesis related genes in response to Tobacco mosaic virus. JAPS J. Anim. Plant Sci. 2019, 29, 1596-1602.

38. Abdelkhalek, A.; Ismail, I.A.; Dessoky, E.S.; El-Hallous, E.I.; Hafez, E. A tomato kinesin-like protein is associated with Tobacco mosaic virus infection. Biotechnol. Biotechnol. Equip. 2019, 33, 1424-1433. [CrossRef]

39. Heath, R.L.; Packer, L. Photoperoxidation in isolated chloroplasts: I. Kinetics and stoichiometry of fatty acid peroxidation. Arch Biochem. Biophys. 1968, 125, 189-198. [CrossRef]

40. Velikova, V.; Yordanov, I.; Edreva, A. Oxidative stress and some antioxidant systems in acid rain-treated bean plants: Protective role of exogenous polyamines. Plant Sci. 2000, 151, 59-66. [CrossRef]

41. Cho, Y.K.; Ahn, H.K. Purification and characterization of polyphenol oxidase from potato: II. Inhibition and catalytic mechanism. J. Food Biochem. 1999, 23, 593-605. [CrossRef]

42. Cakmak, I.; Marschner, H. Magnesium Deficiency and High Light Intensity Enhance Activities of Superoxide Dismutase, Ascorbate Peroxidase, and Glutathione Reductase in Bean Leaves. Plant Physiol. 1992, 98, 1222-1227. [CrossRef] [PubMed]

43. Beauchamp, C.; Fridovich, I. Superoxide dismutase: Improved assays and an assay applicable to acrylamide gels. Anal. Biochem. 1971, 44, 276-287. [CrossRef]

44. Abdelkhalek, A.; Dessoky, E.S.; Hafez, E. Polyphenolic genes expression pattern and their role in viral resistance in tomato plant infected with Tobacco mosaic virus. Biosci. Res. 2018, 15, 3349-3356.

45. Abo-Zaid, G.A.; Matar, S.M.; Abdelkhalek, A. Induction of Plant Resistance against Tobacco Mosaic Virus Using the Bio-control Agent Streptomyces cellulosae Isolate Actino 48. Agronomy 2020, 10, 1620. [CrossRef]

46. Abdelkhalek, A.; Al-Askar, A.A.; Hafez, E. Differential induction and suppression of the potato innate immune system in response to Alfalfa mosaic virus infection. Physiol. Mol. Plant Pathol. 2020, 110, 101485. [CrossRef]

47. Livak, K.J.; Schmittgen, T.D. Analysis of relative gene expression data using real-time quantitative PCR and the $2^{-\Delta \Delta C T}$ method. Methods 2001, 25, 402-408. [CrossRef]

48. Abdelkhalek, A.; Hafez, E. Plant Viral Diseases in Egypt and Their Control. In Cottage Industry of Biocontrol Agents and Their Applications; Springer: Berlin/Heidelberg, Germany, 2020; pp. 403-421.

49. Błaszczyk, L.; Popiel, D.; Chełkowski, J.; Koczyk, G.; Samuels, G.J.; Sobieralski, K.; Siwulski, M. Species diversity of Trichoderma in Poland. J. Appl. Genet. 2011, 52, 233-243. [CrossRef]

50. Prabhakaran, N.; Prameeladevi, T.; Sathiyabama, M.; Kamil, D. Multiplex PCR for detection and differentiation of diverse Trichoderma species. Ann. Microbiol. 2014, 65, 1591-1595. [CrossRef]

51. Feitosa, Y.B.; Cruz-Magalhães, V.; Argolo-Filho, R.C.; De Souza, J.T.; Loguercio, L.L. Characterization of genetic diversity on tropical Trichoderma germplasm by sequencing of rRNA internal transcribed spacers. BMC Res. Notes 2019, 12, 663. [CrossRef]

52. Matheny, P.B. Improving phylogenetic inference of mushrooms with RPB1 and RPB2 nucleotide sequences (Inocybe; Agaricales). Mol. Phylogenet. Evol. 2005, 35, 1-20. [CrossRef]

53. Devi, P.; Prabhakaran, N.; Kamil, D.; Pandey, P.; Borah, J.L. Characterization of Indian native isolates of Trichoderma spp. and assessment of their bio-control efficiency against plant pathogens. Afr. J. Biotechnol. 2012, 11, 15150-15160.

54. Yedidia, I.; Srivastva, A.K.; Kapulnik, Y.; Chet, I. Effect of Trichoderma harzianum on microelement concentrations and increased growth of cucumber plants. Plant Soil 2001, 235, 235-242. [CrossRef]

55. Harman, G.E. Myths and Dogmas of Biocontrol Changes in Perceptions Derived from Research on Trichoderma harzinum T-22. Plant Dis. 2000, 84, 377-393. [CrossRef] [PubMed]

56. Heflish, A.; Abdelkhalek, A.; Al-Askar, A.; Behiry, S. Protective and Curative Effects of Trichoderma asperelloides Ta41 on Tomato Root Rot Caused by Rhizoctonia solani Rs33. Agronomy 2021, 11, 1162. [CrossRef]

57. Tamandegani, P.R.; Sharifnabi, B.; Massah, A.; Zahravi, M. Induced reprogramming of oxidative stress responses in cu-cumber by Trichoderma asperellum (Iran 3062C) enhances defense against cucumber mosaic virus. Biol. Control. 2021, 164, 104779. [CrossRef]

58. Petrova, D.; Chaneva, G.; Stoimenova, E.; Kapchina-Toteva, V. Effect of cucumber mosaic virus on the contents of chlo-rophyll, proline, the degree of lipid peroxidation and phenotypic expression of pepper lines with different susceptibility to virus. Oxid. Commun. 2012, 35, 182-189. 
59. Martinez-Medina, A.; Roldan, A.; Pascual, J. Performance of a Trichoderma harzianum Bentonite-Vermiculite Formulation Against Fusarium Wilt in Seedling Nursery Melon Plants. HortScience 2009, 44, 2025-2027. [CrossRef]

60. Tchameni, S.N.; Sameza, M.L.; O’Donovan, A.; Fokom, R.; Ngonkeu, E.L.M.; Nana, L.W.; Etoa, F.-X.; Nwaga, D. Antagonism of Trichoderma asperellum against Phytophthora megakarya and its potential to promote cacao growth and induce biochemical defence. Mycology 2017, 8, 84-92. [CrossRef]

61. Harman, G.E. Multifunctional fungal plant symbionts: New tools to enhance plant growth and productivity. New Phytol. 2011, 189, 647-649. [CrossRef]

62. Vitti, A.; Pellegrini, E.; Nali, C.; Lovelli, S.; Sofo, A.; Valerio, M.; Scopa, A.; Nuzzaci, M. Trichoderma harzianum T-22 Induces Systemic Resistance in Tomato Infected by Cucumber mosaic virus. Front. Plant Sci. 2016, 7, 1520. [CrossRef]

63. Huang, H.; Ullah, F.; Zhou, D.-X.; Yi, M.; Zhao, Y. Mechanisms of ROS Regulation of Plant Development and Stress Responses. Front. Plant Sci. 2019, 10, 800. [CrossRef] [PubMed]

64. Taheri, P.; Kakooee, T. Reactive oxygen species accumulation and homeostasis are involved in plant immunity to an opportunistic fungal pathogen. J. Plant Physiol. 2017, 216, 152-163. [CrossRef] [PubMed]

65. Song, X.-S.; Wang, Y.-J.; Mao, W.-H.; Shi, K.; Zhou, Y.-H.; Nogués, S.; Yu, J.-Q. Effects of cucumber mosaic virus infection on electron transport and antioxidant system in chloroplasts and mitochondria of cucumber and tomato leaves. Physiol. Plant. 2009, 135, 246-257. [CrossRef] [PubMed]

66. Sorahinobar, M.; Soltanloo, H.; Niknam, V.; Ebrahimzadeh, H.; Moradi, B.; Safaie, N.; Behmanesh, M.; Bahram, M. Physiological and molecular responses of resistant and susceptible wheat cultivars to Fusarium graminearum mycotoxin extract. Can. J. Plant Pathol. 2017, 39, 444-453. [CrossRef]

67. Luo, Y.; Zhang, D.-D.; Dong, X.-W.; Zhao, P.-B.; Chen, L.-L.; Song, X.-Y.; Wang, X.-J.; Chen, X.-L.; Shi, M.; Zhang, Y.-Z. Antimicrobial peptaibols induce defense responses and systemic resistance in tobacco against tobacco mosaic virus. FEMS Microbiol. Lett. 2010 313, 120-126. [CrossRef]

68. Sobhy, S.E.; Abo-Kassem, E.-E.M.; Sewelam, N.A.; Hafez, E.E.; Aseel, D.G.; Saad-Allah, K.M. Pre-soaking in Weed Extracts is a Reasonable Approach to Mitigate Fusarium graminearum Infection in Wheat. J. Plant Growth Regul. 2021, 1-18. [CrossRef]

69. Loreto, F.; Velikova, V. Isoprene Produced by Leaves Protects the Photosynthetic Apparatus against Ozone Damage, Quenches Ozone Products, and Reduces Lipid Peroxidation of Cellular Membranes. Plant Physiol. 2001, 127, 1781-1787. [CrossRef]

70. Anthony, K.K.; George, D.S.; Singh, H.K.B.; Fung, S.M.; Santhirasegaram, V.; Razali, Z.; Somasundram, C. Reactive Oxygen Species Activity and Antioxidant Properties of Fusarium Infected Bananas. J. Phytopathol. 2017, 165, 213-222. [CrossRef]

71. Garg, N.; Manchanda, G. ROS generation in plants: Boon or bane? Plant Biosyst. 2009, 143, 81-96. [CrossRef]

72. Gill, S.S.; Tuteja, N. Reactive oxygen species and antioxidant machinery in abiotic stress tolerance in crop plants. Plant Physiol. Biochem. 2010, 48, 909-930. [CrossRef]

73. Masuta, C.; Inaba, J.; Shimura, H. The $2 \mathrm{~b}$ proteins of Cucumber mosaic virus generally have the potential to differentially induce necrosis on Arabidopsis. Plant Signal. Behav. 2012, 7, 43-45. [CrossRef] [PubMed]

74. Mathioudakis, M.M.; Veiga, R.S.L.; Canto, T.; Medina, V.; Mossialos, D.; Makris, A.M.; Livieratos, I. P epino mosaic virus triple gene block protein 1 (TGBp1) interacts with and increases tomato catalase 1 activity to enhance virus accumulation. Mol. Plant Pathol. 2013, 14, 589-601. [CrossRef] [PubMed]

75. Mondal, S.; Phadke, R.R.; Badigannavar, A.M. Genetic variability for total phenolics, flavonoids and antioxidant activity of testaless seeds of a peanut recombinant inbred line population and identification of their controlling QTLs. Euphytica 2014, 204, 311-321. [CrossRef]

76. Zhang, P.; Zhou, M.P.; Zhang, X.; Huo, Y.; Ma, H.X. Change of defensive-related enzyme in wheat crown rot seedlings infected byFusarium graminearum. Cereal Res. Commun. 2013, 41, 431-439. [CrossRef]

77. Martinez, C.; Montillet, J.L.; Bresson, E.; Agnel, J.P.; Dai, G.H.; Daniel, J.F.; Geiger, J.P.; Nicole, M. Apoplastic Peroxidase Generates Superoxide Anions in Cells of Cotton Cotyledons Undergoing the Hypersensitive Reaction to Xanthomonas campestris pv. malvacearum Race 18. Mol. Plant-Microbe Interact. 1998, 11, 1038-1047. [CrossRef]

78. Murphy, J.F.; Reddy, M.S.; Ryu, C.-M.; Kloepper, J.W.; Li, R. Rhizobacteria-Mediated Growth Promotion of Tomato Leads to Protection Against Cucumber mosaic virus. Phytopathology 2003, 93, 1301-1307. [CrossRef]

79. Smit, F.; Dubery, I.A. Cell wall reinforcement in cotton hypocotyls in response to a Verticillium dahliae elicitor. Phytochemistry 1997, 44, 811-815. [CrossRef]

80. Li, L.; Steffens, J.C. Overexpression of polyphenol oxidase in transgenic tomato plants results in enhanced bacterial disease resistance. Planta 2002, 215, 239-247. [CrossRef]

81. Robert-Seilaniantz, A.; Navarro, L.; Bari, R.; Jones, J.D. Pathological hormone imbalances. Curr. Opin. Plant Biol. 2007, 10, 372-379. [CrossRef]

82. Niggeweg, R.; Michael, A.J.; Martin, C. Engineering plants with increased levels of the antioxidant chlorogenic acid. Nat. Biotechnol. 2004, 22, 746-754. [CrossRef]

83. Tsao, R.; Marvin, C.H.; Broadbent, A.B.; Friesen, M.; Allen, W.R.; McGarvey, B.D. Evidence for an isobutylamide associated with host-plant resistance to western flower thrips, Frankliniella occidentalis, in chrysanthemum. J. Chem. Ecol. 2005, 31, 103-110. [CrossRef] [PubMed]

84. Leiss, K.A.; Maltese, F.; Choi, Y.H.; Verpoorte, R.; Klinkhamer, P.G. Identification of Chlorogenic Acid as a Resistance Factor for Thrips in Chrysanthemum. Plant Physiol. 2009, 150, 1567-1575. [CrossRef] 
85. Yedidia, I.; Shoresh, M.; Kerem, Z.; Benhamou, N.; Kapulnik, Y.; Chet, I. Concomitant induction of systemic resistance to Pseudomonas syringae pv. lachrymans in cucumber by Trichoderma asperellum (T-203) and accumulation of phytoalexins. Appl. Environ. Microbiol. 2003, 69, 7343-7353. [PubMed]

86. Singh, B.N.; Singh, A.; Singh, S.P.; Singh, H.B. Trichoderma harzianum-mediated reprogramming of oxidative stress response in root apoplast of sunflower enhances defence against Rhizoctonia solani. Eur. J. Plant Pathol. 2011, 131, 121-134. [CrossRef]

87. Dao, T.T.H.; Linthorst, H.J.M.; Verpoorte, R. Chalcone synthase and its functions in plant resistance. Phytochem. Rev. 2011, 10, 397-412. [CrossRef]

88. Abdelkhalek, A.; Al-Askar, A.A.; Behiry, S.I. Bacillus licheniformis strain POT1 mediated polyphenol biosynthetic pathways genes activation and systemic resistance in potato plants against Alfalfa mosaic virus. Sci. Rep. 2020, 10, 16120. [CrossRef] [PubMed]

89. Martínez, G.; Regente, M.; Jacobi, S.; Del Rio, M.; Pinedo, M.; de la Canal, L. Chlorogenic acid is a fungicide active against phytopathogenic fungi. Pestic. Biochem. Physiol. 2017, 140, 30-35. [CrossRef]

90. Kanwal, Q.; Hussain, I.; Siddiqui, H.L.; Javaid, A. Antifungal activity of flavonoids isolated from mango (Mangifera indica L.) leaves. Nat. Prod. Res. 2010, 24, 1907-1914. [CrossRef] [PubMed]

91. Van Loon, L.; Van Strien, E. The families of pathogenesis-related proteins, their activities, and comparative analysis of PR-1 type proteins. Physiol. Mol. Plant Pathol. 1999, 55, 85-97. [CrossRef]

92. ElMorsi, A.; Abdelkhalek, A.; AlShehaby, O.; Hafez, E. Pathogenesis-related genes as tools for discovering the response of onion defence system against Iris yellow spot virus infection. Botany 2015, 93, 735-744. [CrossRef]

93. Hoegen, E.; Strömberg, A.; Pihlgren, U.; Kombrink, E. Primary structure and tissue-specific expression of the pathogenesis-related protein PR-1b in potato. Mol. Plant Pathol. 2002, 3, 329-345. [CrossRef] [PubMed]

94. Abdelkhalek, A.; Qari, S.H.; Abu-Saied, M.A.A.-R.; Khalil, A.M.; Younes, H.A.; Nehela, Y.; Behiry, S.I. Chitosan Nano-particles Inactivate Alfalfa Mosaic Virus Replication and Boost Innate Immunity in Nicotiana glutinosa Plants. Plants 2021, 10, 2701. [CrossRef] [PubMed]

95. Abdelkhalek, A.; Salem, M.Z.; Kordy, A.M.; Salem, A.Z.; Behiry, S.I. Antiviral, antifungal, and insecticidal activities of Eucalyptus bark extract: HPLC analysis of polyphenolic compounds. Microb. Pathog. 2020, 147, 104383. [CrossRef] [PubMed]

96. Abo-Zaid, G.; Abdelkhalek, A.; Matar, S.; Darwish, M.; Abdel-Gayed, M. Application of Bio-Friendly Formulations of ChitinaseProducing Streptomyces cellulosae Actino 48 for Controlling Peanut Soil-Borne Diseases Caused by Sclerotium rolfsii. J. Fungi 2021, 7, 167. [CrossRef]

97. Manganiello, G.; Sacco, A.; Ercolano, M.R.; Vinale, F.; Lanzuise, S.; Pascale, A.; Napolitano, M.; Lombardi, N.; Lorito, M.; Woo, S.L. Modulation of tomato response to Rhizoctonia solani by Trichoderma harzianum and its secondary metabolite harzianic acid. Front. Microbiol. 2018, 9, 1966. [CrossRef]

98. Jordá, L.; Conejero, V.; Vera, P. Characterization of P69E and P69F, Two Differentially Regulated Genes Encoding New Members of the Subtilisin-Like Proteinase Family from Tomato Plants. Plant Physiol. 2000, 122, 67-74. [CrossRef]

99. Roylawar, P.; Panda, S.; Kamble, A. Comparative analysis of BABA and Piriformospora indica mediated priming of de-fence-related genes in tomato against early blight. Physiol. Mol. Plant Pathol. 2015, 91, 88-95. [CrossRef]

100. Villamil, J.C.M.; van der Hoorn, R.; Doehlemann, G. Papain-like cysteine proteases as hubs in plant immunity. New Phytol. 2016, 212, 902-907. [CrossRef]

101. Tornero, P.; Mayda, E.; Gómez, M.D.; Cañas, L.; Conejero, V.; Vera, P. Characterization of LRP, a leucine-rich repeat (LRR) protein from tomato plants that is processed during pathogenesis. Plant J. 1996, 10, 315-330. [CrossRef]

102. Ekchaweng, K.; Evangelisti, E.; Schornack, S.; Tian, M.; Churngchow, N. The plant defense and pathogen counterdefense mediated by Hevea brasiliensis serine protease HbSPA and Phytophthora palmivora extracellular protease inhibitor PpEPI10. PLoS ONE 2017, 12, e0175795. [CrossRef]

103. Gillespie, T.; Boevink, P.; Haupt, S.; Roberts, A.G.; Toth, R.; Valentine, T.; Chapman, S.; Oparka, K.J. Functional Analysis of a DNA-Shuffled Movement Protein Reveals That Microtubules Are Dispensable for the Cell-to-Cell Movement of Tobacco mosaic virus. Plant Cell 2002, 14, 1207-1222. [CrossRef] [PubMed]

104. Kawakami, S.; Watanabe, Y.; Beachy, R.N. Tobacco mosaic virus infection spreads cell to cell as intact replication complexes. Proc. Natl. Acad. Sci. USA 2004, 101, 6291-6296. [CrossRef] [PubMed]

105. Otulak, K.; Garbaczewska, G. Cellular localisation of calcium ions during potato hypersensitive response to Potato virus Y. Micron 2011, 42, 381-391. [CrossRef] [PubMed]

106. Van Wees, S.C.M.; Luijendijk, M.; Smoorenburg, I.; Van Loon, L.C.; Pieterse, C.M.J. Rhizobacteria-mediated induced systemic resistance (ISR) in Arabidopsis is not associated with a direct effect on expression of known defense-related genes but stim-ulates the expression of the jasmonate-inducible gene Atvsp upon challenge. Plant Mol. Biol. 1999, 41, 537-549. [CrossRef]

107. Newman, M.; Von Roepenack-Lahaye, E.; Parr, A.; Daniels, M.J.; Dow, J.M. Prior exposure to lipopolysaccharide potentiates expression of plant defenses in response to bacteria. Plant J. 2002, 29, 487-495. [CrossRef] [PubMed]

108. Oide, S.; Bejai, S.; Staal, J.; Guan, N.; Kaliff, M.; Dixelius, C. A novel role of PR 2 in abscisic acid (ABA) mediated, pathogen-induced callose deposition in Arabidopsis thaliana. New Phytol. 2013, 200, 1187-1199. [CrossRef]

109. Linthorst, H.J.; Melchers, L.S.; Mayer, A.; van Roekel, J.S.; Cornelissen, B.J.; Bol, J.F. Analysis of gene families encoding acidic and basic beta-1,3-glucanases of tobacco. Proc. Natl. Acad. Sci. USA 1990, 87, 8756-8760. [CrossRef] 
110. Rezzonico, E.; Flury, N.; Meins, F.; Beffa, R. Transcriptional down-regulation by abscisic acid of pathogenesis-related $\beta-1$, 3-glucanase genes in tobacco cell cultures. Plant Physiol. 1998, 117, 585-592. [CrossRef]

111. Otulak-Kozieł, K.; Kozieł, E.; Lockhart, B. Plant cell wall dynamics in compatible and incompatible potato response to infection caused by Potato virus Y (PVYNTN). Int. J. Mol. Sci. 2018, 19, 862. [CrossRef]

112. Bucher, G.L.; Tarina, C.; Heinlein, M.; Di Serio, F.; Meins, F., Jr.; Iglesias, V.A. Local expression of enzymatically active class I $\beta-1$, 3-glucanase enhances symptoms of TMV infection in tobacco. Plant J. 2001, 28, 361-369. [CrossRef]

113. Dobnik, D.; Baebler, Š.; Kogovšek, P.; Pompe-Novak, M.; Štebih, D.; Panter, G.; Janež, N.; Morisset, D.; Žel, J.; Gruden, K. $\beta-1$, 3-glucanase class III promotes spread of PVY NTN and improves in planta protein production. Plant Biotechnol. Rep. 2013, 7, 547-555. [CrossRef] [PubMed] 